\title{
BEHAVIOR OF NORMAL STRENGTH CONCRETE SLABS UNDER STATIC AND DYNAMIC LOADS
}

by

Turky Sami Jeddawi

B.Eng, King Abdulaziz University, Saudi Arabia, 2009

\author{
A Master Project Report \\ presented to Ryerson University \\ in partial fulfillment of the \\ requirements for the degree of \\ Master of Engineering \\ in the program of \\ Civil Engineering
}

Toronto, Ontario, Canada, 2017

(C) Turky Sami Jeddawi, 2017 


\section{AUTHOR'S DECLARATION}

I hereby declare that I am the sole author of this MRP. This is a true copy of the MRP, including any required final revisions.

I authorize Ryerson University to lend this MRP to other institutions or individuals for the purpose of scholarly research.

I further authorize Ryerson University to reproduce this MRP by photocopying or by other means, in total or in part, at the request of other institutions or individuals for the purpose of scholarly research.

I understand that my MRP may be made electronically available to the public. 


\title{
BEHAVIOR OF NORMAL STRENGTH CONCRETE SLABS UNDER \\ STATIC AND DYNAMIC LOADS
}

\author{
Turky Sami Jeddawi \\ Master of Engineering in Civil Engineering \\ Ryerson University, Toronto, 2017
}

\begin{abstract}
An experimental investigation has been conducted to determine the deformation and failure characteristic of slab under static and dynamic loads. Two identical reinforced concrete (RC) of dimensions 1950 x 1950 x $100 \mathrm{~mm}$ are tested under same boundary conditions. All top and bottom reinforcement are $10 \mathrm{M}$ doubly plates reinforcement with total $1.0 \%$ steel ratio. The static load is applied at the midpoint of the slab by using load cell $400 \times 400 \mathrm{~mm}$ with a capacity of $250 \mathrm{kN}$. The static load increment used in this investigation is $5 \mathrm{kN}$. The dynamic load is applied at the midpoint of the slab by using a drop-weight of $475 \mathrm{~kg}$ from a height of $4.15 \mathrm{~m}$ generating an impact energy of $19.24 \mathrm{~kJ}$ with impact velocity of $9 \mathrm{~m} / \mathrm{s}$. The experimental results revealed that the absorption energy of the impact loading is about 1.4 times the static loading. The maximum deflection is found to be slightly higher for impact loading.
\end{abstract}




\section{ACKNOWLEDGEMENTS}

My utmost thanks are due to the Almighty Allah, then to my parents, and all who supported me in this project.

My sincere appreciation and gratitude goes to Dr. Hesham Marzouk, my advisor, for his guidance, good suggestions, constant encouragement and precious advice during this project.

I would like to add my heartfelt appreciation for Mr. Hesham Othman who helped me out at every step of this project.

My general thanks for all the faculty members and staff in the Department of Civil Engineering especially Lab technicians, who provided me technical assistance throughout this project, and the Faculty of Engineering and Architectural Science at Ryerson University. 


\section{DEDICATION}

First I am grateful to Allah, who has given me the strength to complete my studies and my project. I would like to dedicate this work to my parents and friends whose continuous support and encouragement inspired me time and again to do well in every facet of my life. 


\section{TABLE OF CONTENTS}

Author's Declaration $\quad$ ii

Abstract $\quad$ iii

Acknowledgments $\quad$ iv

Dedication $\quad \mathrm{V}$

List of Tables $\quad$ ix

List of Figures $\quad$ X

CHAPTER 1: INTRODUCTION 1

1.1 Background 2

1.2 Scope definition 3

1.2.1 Project description 3

1.2.2 Objectives 3

1.2.3 Research methodology 3

1.3 Work plan 4

1.3.1 Formwork 4

1.3.2 Cast and place concrete 4

1.3.3 Test data collective $\quad 4$

1.3.4 Analysis and report 4

1.4 Project outline $\quad 5$

CHAPTER 2: LITERATURE REVIEW

2.1 Introduction $\quad 7$

2.2 Normal strength concrete (NSC)

2.3 Mechanical properties of NSC 8

2.4 Compressive behavior $\quad 8$

2.5 Tension behavior $\quad 9$

2.6 Mixing and casting $\quad 10$

2.7 Concrete strength 11 
2.8 Structural response and failure modes 11

2.8.1 RC plate under static load 11

$\begin{array}{lll}2.8 .2 & \text { RC plate under impact load } & 12\end{array}$

2.9 RC plates experimental testing 13

2.9.1 Review on static load experimental 13

2.9.2 Review on impact load experimental 14

$\begin{array}{ll}2.10 \text { Summary of previous research } & 15\end{array}$

CHAPTER 3: STATIC LOAD TEST 16

$\begin{array}{ll}3.1 \text { Introduction } & 17\end{array}$

3.2 Testing methods for concrete slab under static load 17

3.2.1 Experimental work 18

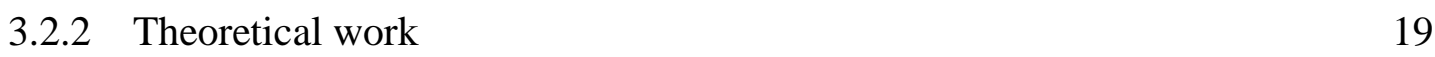

3.3 Experimental program $\quad 22$

3.3.1 Materials 22

3.3.2 Specimen 23

$\begin{array}{lll}3.3 .3 & \text { Test procedure } & 24\end{array}$

3.4 Test result 26

3.4.1 Load-Deflection characteristics 27

3.4.2 Ductility and energy absorption characteristics 28

$\begin{array}{lll}3.4 .3 & \text { Steel strain } & 29\end{array}$

3.4.4 Crack and failure mode 30

3.5 Theoretical result 31

3.6 Discussion of the static results 33

CHAPTER 4: DYNAMIC LOAD TEST 34

4.1 Introduction 35

4.2 Testing methods for concrete slab under dynamic load 36

4.2.1 Experimental work 36

$\begin{array}{lll}\text { 4.2.2 Test data filtering } & 37\end{array}$ 
4.3 Experimental program 38

4.3.1 Materials 38

4.3.2 Specimen 39

4.3.3 Test procedure 41

4.3.4 Test termination criteria 43

$\begin{array}{ll}4.4 \text { Test result } & 43\end{array}$

4.4.1 Impact force and total reaction force 44

4.4.2 Displacement 47

4.4.3 Damage 49

4.5 Discussion of the dynamic results $\quad 50$

CHAPTER 5: SUMMARY AND CONCLUSION 52

5.1 Introduction $\quad 53$

5.2 Research findings 53

5.3 Recommendation for future studies $\quad 54$

APPENDIX: WORKSHOP PICTURES

$\begin{array}{ll}\text { REFERENCES } & 58\end{array}$ 


\section{LIST OF TABLES}

Table 2.1 Typical mechanical properties of NSC $\quad 8$

$\begin{array}{lll}\text { Table } 3.1 & \text { Static specimen details } & 23\end{array}$

Table 3.2 Deflection characteristics of the slab 27

Table 3.3 Ductility, Stiffness, and Energy absorption for static test 29

Table $3.4 \quad$ Static specimen parameter 32

Table 3.5 Comparison of yield line method with experimental result 32

Table 3.6 CSA A23.3-04 code result 32

Table 3.7 ACI 318-11 code result $\quad 32$

Table 3.8 Comparison of CSA and ACI codes with test result 32

Table 4.1 Properties of NSC and Steel 39

Table 4.2 Details of the dynamic test specimen 40

Table 4.3 Peak measurements and time if the test result 43

$\begin{array}{lll}\text { Table } 4.4 & \text { Force characteristic value } & 44\end{array}$

$\begin{array}{lll}\text { Table } 4.5 & \text { Damage measurements } & 49\end{array}$ 


\section{LIST OF FIGURES}

$\begin{array}{lll}\text { Figure 2.1 Typical compressive stress-strain curve of NSC } & 9\end{array}$

$\begin{array}{lll}\text { Figure 2.2 Global response of RC target } & 12\end{array}$

$\begin{array}{lll}\text { Figure 2.3 Local response of RC target } & 13\end{array}$

$\begin{array}{lll}\text { Figure 3.1 Specimen yield line layout } & 20\end{array}$

$\begin{array}{lll}\text { Figure 3.2 Normal strength concrete casting } & 22\end{array}$

$\begin{array}{lll}\text { Figure 3.3 Specimen reinforcement details } & 23\end{array}$

$\begin{array}{lll}\text { Figure } 3.4 & \text { Static specimen mold } & 24\end{array}$

$\begin{array}{lll}\text { Figure } 3.5 & \text { Static test setup } & 25\end{array}$

$\begin{array}{lll}\text { Figure 3.6 Specimen setting layout } & 25\end{array}$

$\begin{array}{lll}\text { Figure 3.7 Static test sensors and equipment } & 26\end{array}$

$\begin{array}{lll}\text { Figure } 3.8 & \text { Static load vs deflection curve } & 28\end{array}$

$\begin{array}{lll}\text { Figure } 3.9 & \text { Stress strain curve } & 29\end{array}$

$\begin{array}{lll}\text { Figure 3.10 Static test cracks pattern } & 30\end{array}$

$\begin{array}{lll}\text { Figure 4.1 Velocity - Time histories data } & 37\end{array}$

$\begin{array}{lll}\text { Figure 4.2 Acceleration - Time histories data } 38 & 38\end{array}$

$\begin{array}{lll}\text { Figure } 4.3 & \text { Dynamic specimen mold } & 40\end{array}$

$\begin{array}{lll}\text { Figure } 4.4 & \text { Reinforcement details of the specimen } & 40\end{array}$

$\begin{array}{lll}\text { Figure } 4.5 & \text { Dynamic test setup } & 42\end{array}$

$\begin{array}{lll}\text { Figure } 4.6 & \text { Dynamic test sensors } & 42\end{array}$

Figure 4.7 Impact and reaction time histories 44

Figure 4.8 Impact force time histories for drop 1 45

Figure 4.9 Impact force time histories for drop 2 46

$\begin{array}{lll}\text { Figure } 4.10 \quad \text { Absorbed Energy } & 47\end{array}$

$\begin{array}{lll}\text { Figure 4.11 Displacement time histories } & 48\end{array}$

$\begin{array}{lll}\text { Figure 4.12 Displacement time histories for first vs second impact test } & 48\end{array}$

$\begin{array}{lll}\text { Figure 4.13 Steel strain time histories } & 49\end{array}$

$\begin{array}{llr}\text { Figure } 4.14 \text { Cracks pattern } & 50\end{array}$ 


\section{CHAPTER 1}

INTRODUCTION 


\section{INTRODUCTION}

\subsection{Background}

The Structure industry has been prescribed as the engine that drives the overall economy. It represents one of the largest economic sectors all around the world. Until the early 1980s the construction industry accounted for the largest percent of the gross domestic product and had the highest dollar turnover of any U.S. industry.

Reinforced concrete buildings are generally designed to behave in a ductile manner under the action. To achieve such ductile behavior, structural members of the buildings should be carefully detailed. The most fundamental issue in predicting the behavior of reinforced concrete members is the stress-strain behavior of the constituent materials.

Concrete is used to resist compression and its behavior in compression is important to the designer. If the behavior of concrete subjected to load is known, the flexural behavior of reinforced concrete can be estimated.

Plain concrete has poor dynamic performance, which makes it potentially unsuitable for structures that require to-resist impact, shock and explosive loading. These structures include bridges, gas tanks, offshore structures, nuclear reactor containment shields, heavy-duty runways, defense shelter, crash barriers, seismic resistance structures, and structures of military and strategic importance designed to withstand explosive blast.

Normal Strength Concrete (NSC) is the lay term for concrete that is produced by following the mixing instructions that are commonly published on packets of cement, typically using sand or aggregate, and often mixed in improvised containers. Despite of compressive strength and durability, NSC shows poor tensile and flexural strength which make it prone to cracking, and gradual increase of brittleness. However, the addition of reinforcement steel in the design results in high flexural strength for the slab. Many types of pre-mixed concrete are available which include powdered cement mixed with an aggregate, needing only water (ACI, 1991). This study will investigate and compare the failure mode characteristic of normal concrete slabs subjected to static and low-velocity impact. 


\subsection{Scope definition}

\subsubsection{Project description}

The project is to determine the punching failure mode for normal reinforced concrete slabs simply supported at their corners in order to investigate the slab behavior under static and dynamic loads.

\subsubsection{Objectives}

The main objectives of the work in this project are:

- Investigate the normal reinforcement concrete slab behavior under static and dynamic loads.

- Characterize of the concrete ductility, energy absorption, cracks, and failure mode.

- Evaluate and compare the predictive punching failure between world's most use analytical techniques.

- Create a reference test data that will be used later for research data of High Strength Concrete (HSC) and Ultra High Strength Concrete (UHSC) for the same slab configurations and to validate the numerical study.

\subsubsection{Research methodology}

In order to fulfill the objectives of this study, the experimental program is designed to investigate the behavior of normal concrete under static and dynamic loads. The experimental program aims to develop a fundamental understanding of failure mode characteristics of different load types. Two identically reinforced concrete slabs using NSC are tested. Deformation and failure mode of each slab are investigated. One under static load and the other under dynamic load. Finally, obtained results are evaluated and discussed. Appendix, shows the plate frame and some workshop pictures. 


\subsection{Work plan}

The work breakdown structure (WBS) of the project divided into four stages. First: formwork and reinforce steel arrangement. Second: Cast and place the concrete. Third: apply test procedure and data collective. Last: Data analysis and writing report.

\subsubsection{Formwork}

By using plywood, two formwork have been built with $1950 \mathrm{~mm}$ x $1950 \mathrm{~mm}$ and a depth of 100 mm. A $10 \mathrm{M}$ - CSA standard Grade $400 \mathrm{MPa}$ deformed steel bars with spacing $100 \mathrm{~mm}$ are used to form double steel reinforcement top and bottom sides. For static load test, since the applied load is upside down, the top rebar are used to act as main reinforcement "slab tension side", while in the dynamic load test, since the load is as drop-weight, the bottom rebar are used to act as main tension reinforcement.

\subsubsection{Cast and place concrete}

The concrete mix used in this study is NSC with target 28-day cylinder compressive strength of $45 \mathrm{MPa}$. A single normal concrete batch of one cube meter with max nominal size of 0.5 in requested from local supplier.

\subsubsection{Test and Data collective}

Experimental program been conduct and test procedure will be discuss in following chapters. Data acquisition system is used to record the action applied on the slabs.

\subsubsection{Analysis and Report}

The repot should be considered as part of the requirement from Yeates School of Graduate Studies. 


\subsection{Project outline}

This project comprises of five chapters including the introductory chapter. The appendices are also included to provide supporting data for project work.

Chapter 2 is comprised of literature review on NSC and identifies the project program that is undertaken to achieve the desired objective. This section is devoted to review of details of static and dynamic testing procedure.

Chapter 3 identifies the static investigation experimental program and experimental basis on which this program is formulated.

Chapter 4 identifies the dynamic investigation experimental program and experimental basis on which this program is formulated.

Chapter 5 includes the summary and the conclusion of the project. In this chapter major findings in project is discussed. 


\section{CHAPTER 2}

LITERATURE REVIEW 


\section{LITERATURE REVIEW}

\subsection{Introduction}

Reinforced concrete slabs can be of various types. The choice of slab depends on various factors, such as structural heights, span lengths and the need for ducts. Slabs can be considered to carry the load in one or two directions, distinguishing them into one-way or two-way slabs. One-way slabs are supported on opposite supports, while bidirectional supports enable two-way action. Flat slabs are always two-way slabs as the load is transferred in both main directions and distributed between the supports.

Flat slab systems, is a structural system common solution for multi-story residential buildings and office complexes, are favorable due to their sparse demand for space and possibility to be hidden inside non load carrying walls. The structural system makes it possible to use large areas of glass in the facades and allow a more flexible window positioning. The critical failure mode for flat slabs is punching shear; a phenomenon in slabs caused by concentrated load inducing a cone shaped perforation starting from the top surface of the slab.

This chapter summarizes the literature reviewed related to achieve the work associated for the project.

\subsection{Normal strength concrete}

Normal strength concrete (NSC) is a simple material in appearance but has a very complex internal nature. Despite its internal complexity, the versatility, durability, and economy of concrete have made it the world's most used construction material. This can be seen in the variety of structures for which it is used, from highways and bridges to buildings and dams. NSC is a mixture of cement, water, and aggregates, with or without admixtures. Cement and water form a paste that hardens due to chemical reactions between the cement and water. The paste acts as a glue, binding the aggregates, composed of sand and gravel or crushed stone, into a solid rock-like mass. Paste qualities are directly related to the amount of water used in relation to the amount of cement. The less water used, the better the quality of the concrete. Reduced water content results in improved 
strength and durability and reduced permeability and shrinkage. NSC typically has a compressive strength up to $45 \mathrm{MPa}$.

\subsection{Mechanical properties of NSC}

The mechanical properties presented in this section are the important quasi-static properties related to the current study. Table 2.1 summarizes the typical properties of normal strength Portland cement concrete (ASTM C150, 2016).

Table. 2.1: Typical mechanical properties of NSC

\begin{tabular}{c|c}
\hline \hline Mechanical characteristic & Range \\
\hline \hline Density (kg/m3) & $2240-2400$ \\
\hline Compressive strength f'c (MPa) & $20-45$ \\
\hline Flexural strength (MPa) & $3-5$ \\
\hline Elastic Modulus Ec $(\mathrm{GPa})$ & $14-41$ \\
\hline Direct tensile strength $(\mathrm{MPa})$ & $2-5$ \\
\hline Poisson's ratio & $0.20-0.21$ \\
\hline Shear strength (MPa) & $6-17$ \\
\hline Setting time (minutes) & $30-90$ \\
\hline Air content $(\%)$ & $1-2$ \\
\hline$-0-0$
\end{tabular}

\subsection{Compressive behavior}

Figure 2.1 illustrates a typical measured full stress-strain curve of concrete under axial compression, which can be divided into two parts, the ascending branch $(\mathrm{O}-\mathrm{C})$ and the descending branch $(\mathrm{C}-\mathrm{F})$. In the ascending branch, segment $(\mathrm{O}-\mathrm{A})\left(\sigma_{\mathrm{c}}<0.3 \mathrm{f}_{\mathrm{c}}{ }^{\prime}\right)$ is approximately a straight line (Xianglin et al., 2006). The deformation of concrete is mainly due to the elastic deformation of aggregates and cement crystals, while the influence of the viscous flow of hydrated cement paste and the evolution of initial micro-cracks are small. With the increase of stress $\left(0.3 \mathrm{f}_{\mathrm{c}}{ }^{\prime}<\sigma_{\mathrm{c}}<0.8\right.$ $\left.\mathrm{f}_{\mathrm{c}}{ }^{\prime}\right)$, the ascending slope of the curve gradually decreases due to the viscous flow of unhardened gel in concrete and the propagation and growth of micro-cracks. When the stress is increased nearly 
to the axial compressive strength $\left(0.8 \mathrm{fc}<\sigma_{\mathrm{c}}=\mathrm{f}_{\mathrm{c}}{ }^{\prime}\right)$, large strain energy is stored in the specimen, internal cracks speed their propagation, and the cracks parallel to the axial load link together, which means the specimen is about to fail. Generally, the axial compressive strength $f_{c}$ ' of concrete corresponding to the peak point $\mathrm{c}$ in the stress-strain curve and the strain at point $\mathrm{c}$ is called the peak strain $\varepsilon_{\mathrm{c}}$, whose value approximates 0.0035. After point $\mathrm{c}$, further development and connection of continuous cracks damages the prismatic specimen more and more severely, causing the specimen to lose its capacity gradually as shown by the descending branch (C-F) in Fig. 2.1. The descending branch is hard to record by ordinary test machines because with the decrease of stress, the strain energy stored in the machine is released and the sudden recovery deformation of the machine will surely crush the already severely damaged specimen (Xianglin et al., 2006; ASTM C39, 2001).

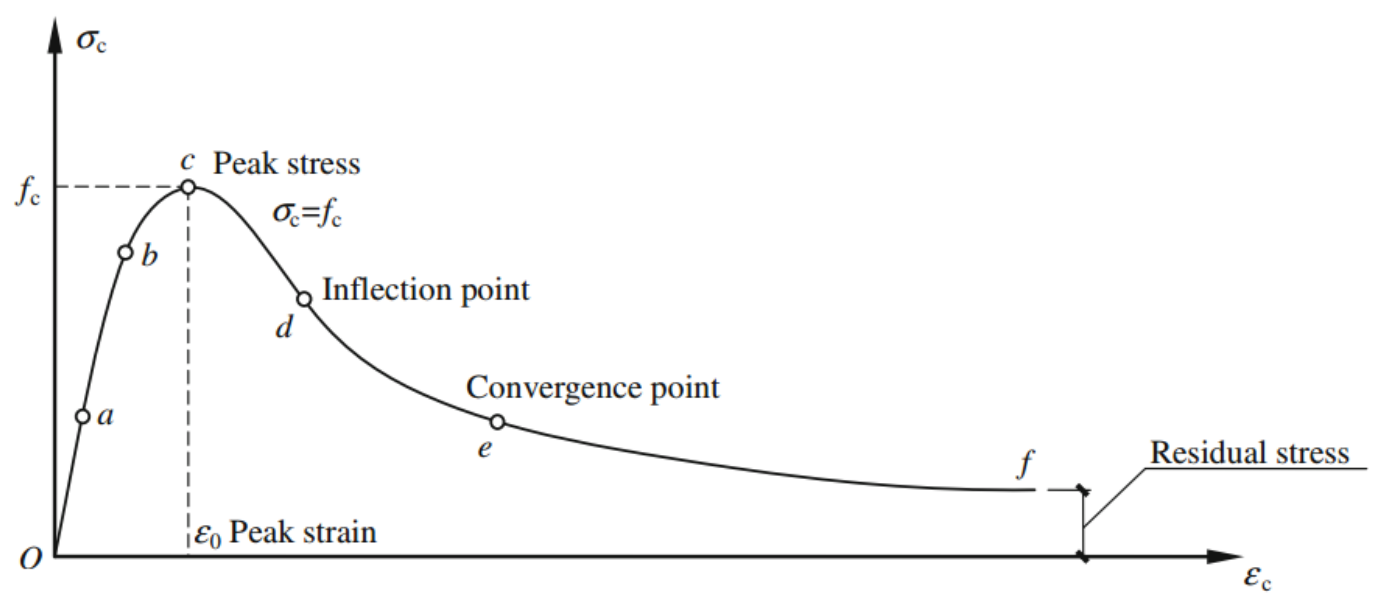

Fig. 2.1: Typical compressive stress-strain curve of NSC

\subsection{Tension behavior}

The stress-strain curves of concrete under axial tension are similar to those under axial compression in shape and also include the ascending and descending branch. But the slope of the descending branch is steep and may become steeper with the increase of the strength grade of concrete (Reinhardt et al., 1986). Since the axial tensile strength is much lower than the axial compressive strength, the stress-strain relationship of concrete under axial tension can be simulated by a bilinear model and the modulus of elasticity of concrete under tension and compression are assumed to be the same (Xianglin et al., 2006; ASTM C496, 2004). 


\subsection{Mixing and casting}

Concrete is mixed in central mixers at ready-mix plants. Ready-mixed concrete can be manufactured by any of the following methods:

- Centrally mixed concrete is completely mixed in a stationary mixer and then delivered in a truck agitator or in a truck mixer at agitating speed to the job site.

- Shrink-mixed concrete is partially mixed in a stationary mixer and completed in a truck mixer.

- $\quad$ Truck-mixed concrete is mixed completely in a truck mixer.

When concrete has been transported to the lab, it is conveyed by bucket. The main constrains were the concrete should be conveyed in such a manner that it is not allowed to dry out and it should not be allowed to segregate before it is placed. Concrete should be deposited continuously as near as possible to its final position (Kosmatka et al., 2006).

Freshly mixed concrete should be plastic or in a semifluid state that can be molded by hand or by mechanical means. In a plastic concrete mixture, all the particles of sand and coarse aggregate are encased and held in suspension. The ingredients should not segregate or separate during transport or handling. A uniform distribution of aggregate particles helps control segregation. After the concrete hardens, it becomes a homogeneous mixture of all the components (Bazant and Cedolin, 1980).

NSC usually has good workability as long as concrete ingredients are used in proper proportions and an adequate aggregate gradation is used. Concrete should be workable but should not segregate or bleed excessively. Bleeding is the development of a layer of water at the top of freshly placed concrete that is caused by settlement of solid particles of cement and aggregate and the simultaneous upward migration of water. A small amount of bleeding is normal and will not affect the durability or strength of the concrete; however, excessive bleeding can result in high water/cement ratios that can cause durability and surface-strength problems. Finishing should be performed after the presence of bleed water is gone (Kosmatka et al., 2006).

To achieve desired strength and durability, concrete must be consolidated to form a homogeneous mass without the presence of large voids. Internal or external vibration of concrete, using vibrators, allows concrete to be properly densified (Bischoff and Perry, 1991). 


\subsection{Concrete strength}

Concrete gains strength through the reaction between cement and water called Hydration. During the first few hours, the cement in the concrete slowly reacts with water, giving the concrete some early strength. This period of early hardening is the setting time. Initial set is defined as the time at which concrete has attained approximately $3.5 \mathrm{MPa}$; final set is defined as the time at which it reaches approximately 27.6 MPa, based on penetration resistance (Lange, 1994). The compressive strength of concrete is directly related to the water/cement ratio. A decrease in water/cement ratio results in higher strength. The compressive strength of concrete increases with age as long as an appropriate moisture content and temperature are available. The compressive strength of concrete at 7 days is approximately $75 \%$ of the 28 -day compressive strength of concrete. Compressive strength is usually specified at the age of 28 days. To maintain this increase in strength, concrete must be properly cured. Curing means that not only must a favorable temperature be present but also moisture loss will not be permitted or extra water will be provided at the surface. Use of a wet burlap or plastic covering for 7 days or use of a curing compound usually provides adequate curing for NSC (Lange, 1994).

\subsection{Structural response and failure modes}

\subsubsection{RC plate under static load}

Modes of failure of conventional two-way plates under static load can be classified into three categories (Murtiadi and Marzouk, 2001):

- Pure flexural failure takes place in plates where most of the reinforcement yields before punching occur. Consequently, the plates exhibit large deflections prior the failure. Usually this type of failure happens in the case of lightly reinforced plates. As the reinforcement ratio decreases, more steel yielding approaches to the total area of the tension steel reinforcement.

- Pure shear failure occurs when the yielding of the tension steel is much localized at the center of loading. Usually, specimens with heavy reinforcement ratio failed under punching shear.

- Ductile shear failure which is a case of transition between pure punching and pure flexure failures. 


\subsubsection{RC plate under impact load}

Impact loading may be classified as hard or soft impact, depending on the deformation of the impactor (projectile) with respect to the deformation of the target. In hard impact, the deformation of the impactor is considerably negligible compared with target's deformation. In such impact type, the impactor is considered rigid. In contrast, in soft impact, the impactor itself undergoes significant deformation and must be considered in the analysis of impact problem (Li et al., 2005; Barr et al., 1982). Static load is classified as constant force for period of time. In either of two load types, the response as well as the failure mode of the concrete target may be classified as follows:

- Global response: the RC member responds globally with a deformation of entire member. There are two failure modes of global response for RC members: flexural failure and punching shear failure. Fig. 2.2 shows the two modes of global response. The majority of global response investigations are carried out on RC beams (Soleimani et al., 2007).

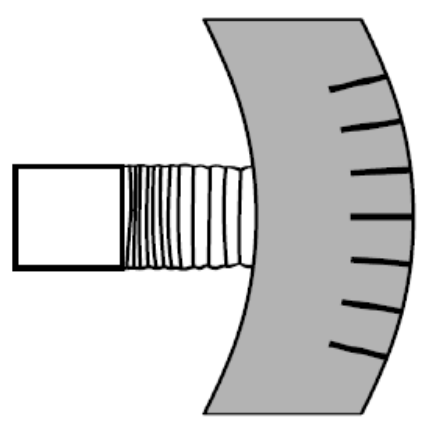

(a) Flexural failure

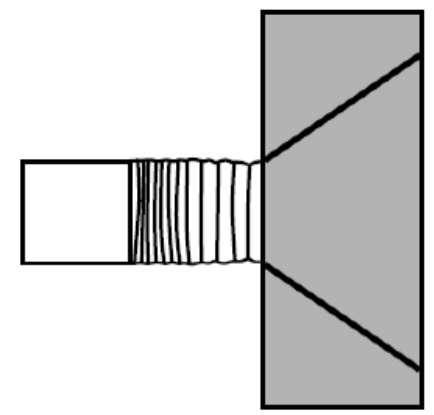

(b) Punching Shear failure

Fig. 2.2: Global response of RC target

- Local response: Most of local response investigations were carried out on RC plates. Local response is briefly sub-divided into seven phenomena as classified in (Kennedy, 1976; Kishi et al., 2002): a) penetration, b) cone cracking and plugging, c) spalling, d) radial cracking, e) scabbing ejection of fragments from the back face of the target, $\mathrm{f}$ ) perforation. Local response damage mechanisms are illustrated in Fig. 2.3. 


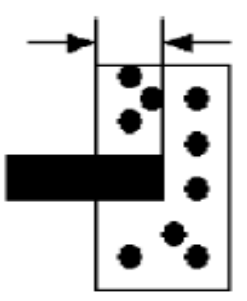

(a)

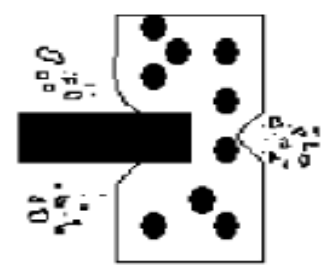

(e)

(b)
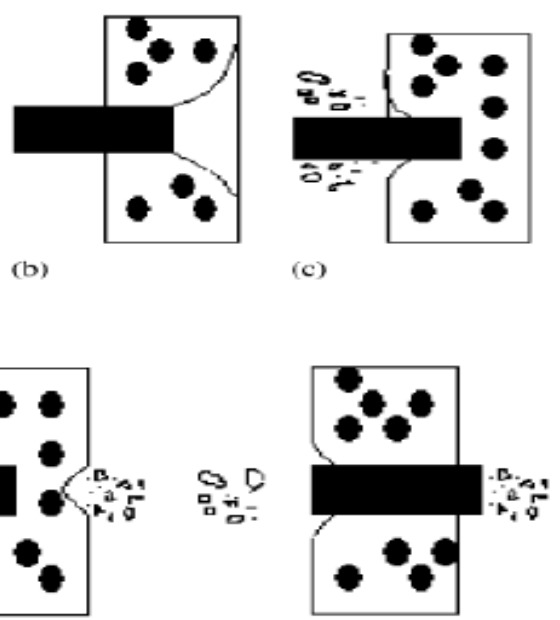

(f)

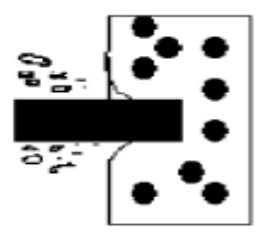

(c)

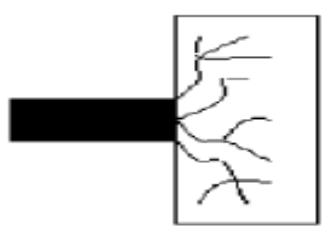

(d)

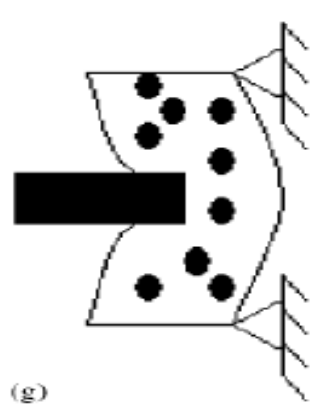

Fig. 2.3: Local response of RC target

- Combined response: the kinetic energy is dissipated through a combination of local and overall structure deformations.

\subsection{RC plates experimental testing}

\subsubsection{Review on static load experimental}

Murtiadi and Marzouk (2001) tested sixteen concrete plates with dimension of $950 \mathrm{~mm}$ x $950 \mathrm{~mm}$ and $100 \mathrm{~mm}$ thickness under both static and dynamic loads. The static investigation was conducted with respect to the North American code and some European design codes to evaluate the test results. The variations of concrete strength (NSC and HSC), boundary conditions (fixed and simply supported), and steel reinforcement ratio (1.0, 2.5\% in tension face, and 0.7, $0.8 \%$ in compression face) were considered. The structural behavior with respect to displacement, load capacities, concrete and steel strains, failure mode, and energy absorption were investigated. The experimental results showed that; the impact punching load at failure was about twice the static punching shear capacity, the ratio of impact versus static fracture energy for HSC plates was found to be much higher than that for NSC, and supporting conditions had little influence on the impact response. 
Marzouk and Hussein (1991) tested seventeen concrete plates with dimension of $1700 \mathrm{~mm}$ x 1700 $\mathrm{mm}$ and $120 \mathrm{~mm}$ thickness under both static loads. The load was applied to the center of the slab through the stub column by using a closed-loop (MTS) testing machine with a maximum capacity of $670 \mathrm{kN}$. The variations of concrete strength (NSC and HSC), boundary conditions simply supported, and steel reinforcement ratio from $0.49 \%$ to $2.33 \%$ were considered. The deformation and structural strength characteristics of punching shear failure were investigated. The experimental results revealed that HSC slabs exhibit a more brittle failure than NSC. Furthermore, the punching strength of the slab is in direct proportion with the level of reinforcement. And using the cubic root of the concrete compressive strength to predict the punching resistance of the concrete slabs generally yields better results than the square root expression used in North American codes.

\subsubsection{Review on impact load experimental}

Sawan and Abdel-Rohman (1987) carried out low-velocity tests on $750 \mathrm{~mm}$ square RC plates, 50 $\mathrm{mm}$ thick. The plates were impacted at their midpoint by free fall steel ball of $120 \mathrm{~mm}$ diameter from several heights up to $1200 \mathrm{~mm}$. The aim of the study was to investigate the effect of impact velocity and steel reinforcement ratio on the dynamic deflection. The results showed steel reinforcement has a little effect on reducing the dynamic deflection of RC slabs.

Kishi et al. (1997) tested nine large rectangular plates of dimensions $4 \times 5 \mathrm{~m}$ under repeated impact. The plate thicknesses were varied $(250,500,750 \mathrm{~mm})$, plates were impacted at their center by free fall masses of $(1000,3000,5000 \mathrm{~kg})$ depending on the thickness. The failure was assumed when the accumulated residual deflection under repeated impact exceeds $1 / 200^{\text {th }}$ the span. The variations of reinforcement ratio $(0.5,1.0 \%)$, reinforcement arrangement (single and double layers) were considered. The purpose of the Kishi et al. (1997) experiments were to investigate the impact behavior by recording maximum impact load, reactions, residual displacements and crack patterns. The results showed that the maximum impact force was affected by plate thickness rather than reinforcement ratio and reinforcement arrangement. 


\subsection{Summary of previous research}

Several static and low-velocity impact experiments that related to this research have been undertaken to understand the static and dynamic response of $\mathrm{RC}$ members. These experimental investigations have revealed that: punching shear is the predominate failure pattern; the impact punching capacity is twice the static one; the supporting conditions have limited effect on RC plate response, failure pattern, impact capacity, and maximum impact force; the plate thickness has significant effect on impact capacity and maximum impact force; and steel reinforcement ratio has a significant effect in controlling spalling. 


\section{CHAPTER 3}

STATIC LOAD TEST 


\section{STATIC LOAD TEST}

\subsection{Introduction}

The two way slab system is a unique efficient structural system. It is economical and is widely used in different structural applications such as floors, roofs and walls of buildings. The two way slab system is also used as a structural component in concrete offshore platforms and nuclear containment structures.

A major concern of this system is localized shear type failure occurs in the immediate nearness of the load and usually is referred to a punching shear failure. The catastrophic nature of punching shear failure is undesirable since an overall yield mechanism will not develop before punching occur. Hence, it has been a major concern for engineers for many years. Detecting cracks and local damages as early as possible is one of the most essential functions of a successful Structure Health Monitoring System (SHM).

NSC is one of the main worldwide cementitious construction materials. And most of structures are subjected to static loading conditions. This test presents the details of a well-organized and equipped experimental, aiming to study the static behaviors of NSC slab. The behavior with regard to the deformation and strength characteristic of NSC slab were studied.

\subsection{Testing methods for concrete slab under Static load}

This test presents the details of a well-organized and equipped experimental, aiming to study the static behaviors with regard to the deformation and strength characteristic of NSC slabs. The following sections summarize the processes required to perform the tasks: 


\subsubsection{Experimental work}

NSC-S is an abbreviation stand for Normal Strength Concrete slab under static testing. One double reinforced NSC slab $1950 \mathrm{~mm}$ square $100 \mathrm{~mm}$ thickness with 1.0\% CSA standards Grade 400 deformed steel bars size of $10 \mathrm{M}$ formed as double steel gage spacing $100 \mathrm{~mm}$ (Fig 3.3). The top steel rebar represent the main reinforcement for the specimen (Fig 3.4). The concrete is completely mixed in a stationary mixer, NSC with target 28-day cylinder-compressive strength of $45 \mathrm{MPa}$, and then delivered in a truck mixer at agitating speed to the lab (Fig.3.2).

The specimen was supported by Four pedestal used in all around the slab corner with center to center $1700 \mathrm{~mm}$ provide a pin support. To measure the support reaction, Four load cell been attached to the pedestal. Four HSS beam $152 \mathrm{~mm}$ x $152 \mathrm{~mm}$ x $12.7 \mathrm{~mm}$ were used to provide a fixation for the supports. $40 \mathrm{~mm}$ diameter rods were used to hold the HSS beam.

A hydraulic jack with maximum capacity of $250 \mathrm{kN}$ lifting up a load cell providing $400 \mathrm{~mm}$ x 400 mm impact area at the middle of the slab. A computer system was used In order to record the applied load and the deflection of the slab called Data Acquisition System. One LVDT was used to measure the slab deflection at mid span upper face since the applied load was upside down. One steel strain gauge been attached to the middle rebar in the tension part of the slab (upper portion) to determine the magnitude and rate of strain in the steel reinforcement. And it has installed as following:

- Grinding the face of rebar of $15 \mathrm{~mm}$ at the middle where the maximum steel strain will be.

- Clean the grinding area by: First, Use grime grabbers to wipe the grinding area. Second, Clean the surface by a water based Alkaline. Last, Clean the surface by a water based Acidic.

- Use the 200 Catalyst-C with M-Bond adhesive to install the strain gauge to his location.

- Use small plastic strap to hold the gauge.

- Cover the gauge by plastic cover.

- Use a silicon and tape adhesives to cover the area to protect the sensor during casting the concrete. 


\subsubsection{Theoretical work}

Theoretical work are the analytical tools for predict the behavior of the slab. It's used to compare the experimental work with three world most use analytical technique.

- CSA.A23.3 (2014) Code: Its Canadian Standard Association Code for Design of Concrete Structures. Refer to Clause 13.3.4, for calculate maximum shear stress resistance without shear reinforcement for concentrated loads, the factored shear stress resistance $\mathrm{v}_{\mathrm{r}}$ shall be the smallest of :

$$
\begin{aligned}
& \mathrm{V}_{\mathrm{r} 1}=\left(1+2 / \beta_{\mathrm{c}}\right) \times 0.19 \lambda \varphi_{\mathrm{c}}\left(\mathrm{f}_{\mathrm{c}}^{0.5}\right) \\
& \mathrm{V}_{\mathrm{r} 2}=\left(0.19+\left(\alpha_{\mathrm{s}} \mathrm{d} / \mathrm{b}_{0}\right)\right) \times \lambda \times \varphi_{\mathrm{c} \times}\left(\mathrm{f}_{\mathrm{c}}^{0.5}\right) \\
& \mathrm{V}_{\mathrm{r} 3}=0.38 \times\left(\mathrm{f}_{\mathrm{c}}^{0.5}\right) \times \lambda \times \varphi_{\mathrm{c}}
\end{aligned}
$$

Where:

$\beta_{c}=$ the ratio of long side to short side of the concentrated load.

$\mathrm{f}_{\mathrm{c}}=$ specified compressive strength of concrete.

$\lambda=$ factor to account for low-density concrete.

$\varphi_{\mathrm{c}}=$ resistance factor for concrete.

$\alpha_{s}=4$ for interior columns, 3 for edge columns, and 2 for corner columns.

$\mathrm{b}_{0}=$ perimeter of critical section for shear in slab.

$\mathrm{d}=$ distance from extreme compression fibre to centroid of longitudinal tension rebar.

- ACI 318 (2011) Code: It's American Concrete Institute Code for Design of Concrete Structures. Refer to Clause 11.11.2.1, for a design of shear for two way action in Non prestressed slabs, the shear stress $\mathrm{v}_{\mathrm{c}}$ shall be the smallest of:

$$
\begin{aligned}
& \mathrm{V}_{\mathrm{c} 1}=0.17\left(1+2 / \beta_{\mathrm{c}}\right) \times \lambda \times\left(\mathrm{f}_{\mathrm{c}}^{0.5}\right) \\
& \mathrm{V}_{\mathrm{c} 2}=0.083\left(2+\left(\alpha_{\mathrm{s}} \mathrm{d} / \mathrm{b}_{0}\right)\right) \times \lambda \times\left(\mathrm{f}_{\mathrm{c}}^{0.5}\right) \\
& \mathrm{V}_{\mathrm{c} 3}=0.33 \times\left(\mathrm{f}_{\mathrm{c}}^{0.5}\right) \times \lambda
\end{aligned}
$$


Where: $\alpha_{s}=40$ for interior columns, 30 for edge columns, and 20 for corner columns.

- Yield Line Flexural Strength: It is a crack in a reinforced concrete slab across which the reinforcing bars have yielded and along which plastic rotation occurs. It uses to investigate failure mechanisms at the ultimate limit stat (Kennedy and Goodchild, 2004).

Initially, the response of the slab is elastic with the maximum steel stress and deflection occurring at the center of the slab. At this stage, some hairline cracking will occur on the soffit where the flexural tensile capacity of the concrete has been exceeded at mid-span (Kennedy and Goodchild, 2004).

Increasing the load hastens the formation of these hairline cracks, increasing the load further will increase the size of the cracks further and induce yielding of the reinforcement, initiating the formation of large cracks emanating from the point of maximum deflection (Kennedy and Goodchild, 2004).

As illustrated by Fig 3.1, the slab is divided into four rigid plane regions A, B, C and D. Yield lines form the boundaries between the rigid regions, and these regions, in effect, rotate about the yield lines. The regions also pivot about their axes of rotation, which usually lie along lines of support, causing supported loads to move. It is at this juncture that the work dissipated by the hinges in the yield lines rotating is equated to work expended by loads on the regions moving (Kennedy and Goodchild, 2004).

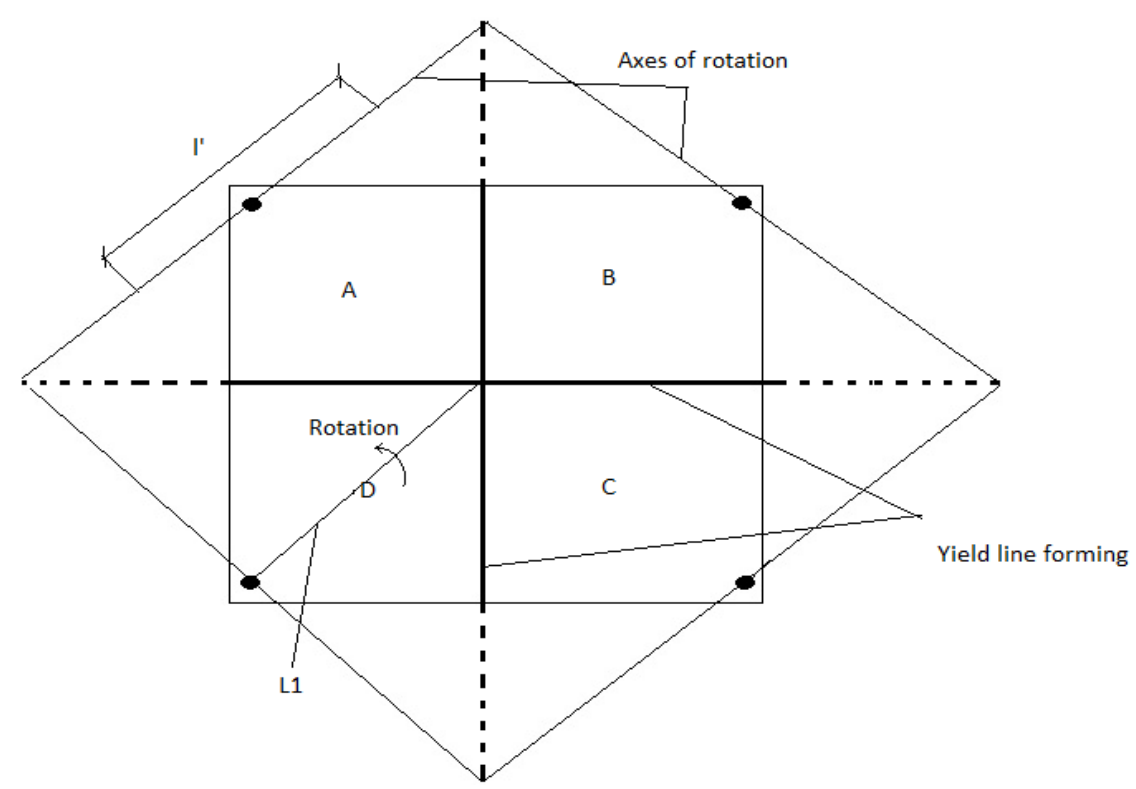

Fig. 3.1: Specimen yield line layout 
The yield line based on the concept of Virtual Work Method, The theory based on the principle that:

Work done in loads moving $=$ Work done in yield lines rotating

External Energy Expended $(E)=$ Internal Energy Dissipated (D)

$$
\Sigma(\mathrm{N} \times \delta)=\Sigma\left(\mathrm{m} \times l^{\prime} \times \theta\right)
$$

Where

$\mathrm{N}=$ load acting $[\mathrm{kN}]$

$\delta=$ the vertical displacement of the load on each region expressed as a fraction of unity $[\mathrm{m}]$

$\mathrm{m}=$ the moment of resistance of the slab per meter $[\mathrm{kNm} / \mathrm{m}]$

$l^{\prime}=$ the projected length onto the axis of rotation for that region $[\mathrm{m}]$

$\theta=$ the rotation of the region about its axis of rotation $[\mathrm{m} / \mathrm{m}]$

For slab configuration Fig 3.1, I will have the following:

Four rigid plane regions had same effect. $(\mathrm{A}=\mathrm{B}=\mathrm{C}=\mathrm{D})$

$l^{\prime}=\mathrm{L}_{1}, \quad \mathrm{~N}=\mathrm{P}, \quad \theta=\delta / \mathrm{L}_{1}, \quad \Sigma=4$

Then, apply the formula (3.7):

$$
\mathrm{P} \times \delta=4 \times \mathrm{m} \times \mathrm{L}_{1} \times \delta / \mathrm{L}_{1}
$$

Will end up with,

$$
\mathrm{P}=\mathrm{k} \times \mathrm{m}, \quad \text { Where } \mathrm{k}=4 \text { based on our support condition }
$$




\subsection{Experimental program}

\subsubsection{Materials}

The concrete mix used in this study is NSC with target 28-day cylinder compressive strength of $45 \mathrm{MPa}$. This matrix includes ordinary Portland cement, quartzite sandstone, and crushed granite of $14 \mathrm{~mm}$ maximum nominal size. This matrix is ready mix concrete provided by local contractor (Fig. 3.2).

The specimen cast using single concrete batch; then cured under moist plastic cover for 7 days. Then, the specimen move out of it molds and placed to dry in laboratory air conditions until testing at the age of 28 days. $10 \mathrm{M}$ - CSA standard Grade $400 \mathrm{MPa}$ deformed steel bars are used as longitudinal reinforcement.

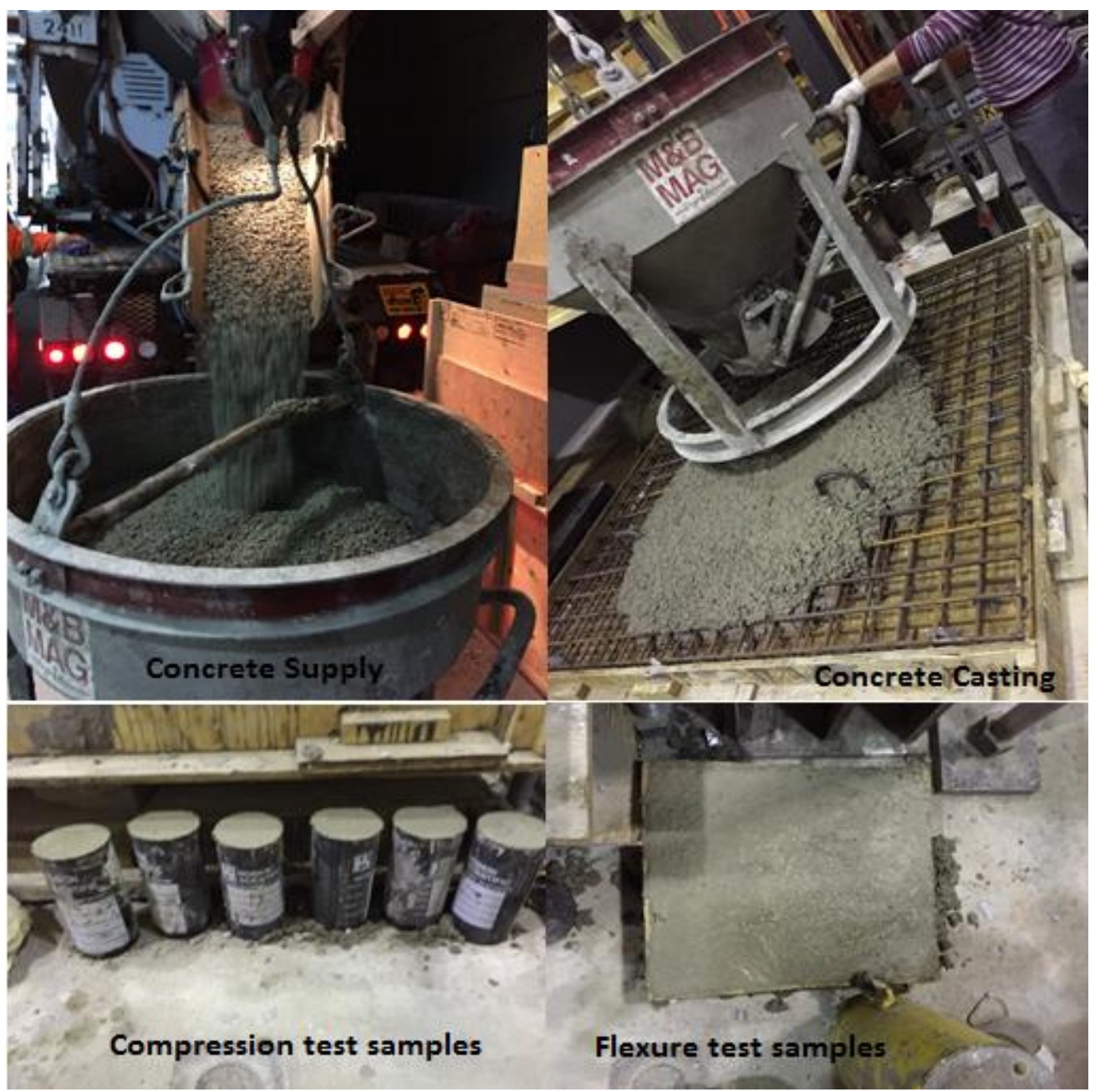

Fig. 3.2: NSC casting 


\subsubsection{Specimen}

Six prisms of dimensions $100 \mathrm{~mm}$ x $100 \mathrm{~mm}$ x $400 \mathrm{~mm}$ leading to flexure test for the mix. Six cylinders of dimensions $100 \mathrm{~mm}$ x $200 \mathrm{~mm}$ leading to compression test for mix. The load had to be applied as uniformly. Both loading faces are grinded before testing (ASTM C39, 2001). The test specimen is simply supported in all four corner. The slab is $1,950 \mathrm{~mm}$ square with a thickness of $100 \mathrm{~mm} .1 .0 \%$ reinforcement ratio of $10 \mathrm{M}$ double steel gage spacing $100 \mathrm{~mm}$ are used for top and bottom reinforcement. Table. 3.1 shown the specimen details. Fig. 3.3-3.4 shows the reinforcement configuration and the specimen mold respectively.

Table. 3.1: Static specimen details

\begin{tabular}{c|c|c|c|c|c|c|c|c}
\hline \hline \multirow{2}{*}{ Slab } & $\begin{array}{c}\text { Compressive } \\
\text { strength }\end{array}$ & $\begin{array}{c}\text { Bar } \\
\text { size }\end{array}$ & $\begin{array}{c}\text { Bar } \\
\text { spacing }\end{array}$ & $\begin{array}{c}\text { Slab } \\
\text { thickness }\end{array}$ & $\begin{array}{c}\text { Concrete } \\
\text { cover }\end{array}$ & $\begin{array}{c}\text { Average } \\
\text { depth }\end{array}$ & $\begin{array}{c}\text { Steel } \\
\text { ratio }\end{array}$ & $\begin{array}{c}\text { Ultimate } \\
\text { steel strain }\end{array}$ \\
& MPA & $m$ & $m$ & $\%$ & $\mathrm{~mm}\left(10^{3}\right)$ \\
\hline \hline NSC-S & 45 & $\mathrm{M} \mathrm{10}$ & 100 & 100 & 15 & 75 & 1 & 2.21 \\
\hline \hline
\end{tabular}

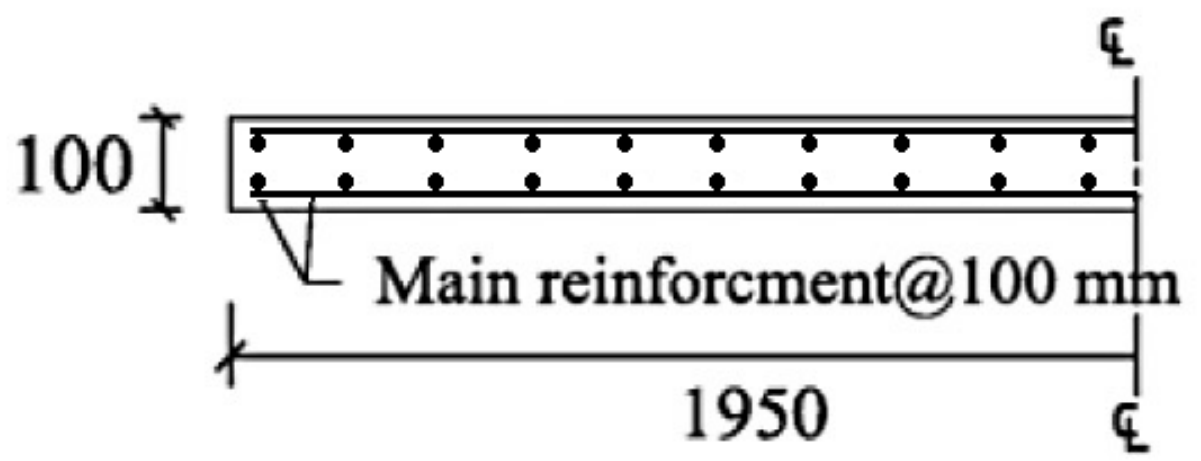

Fig. 3.3: Specimen reinforcement details 


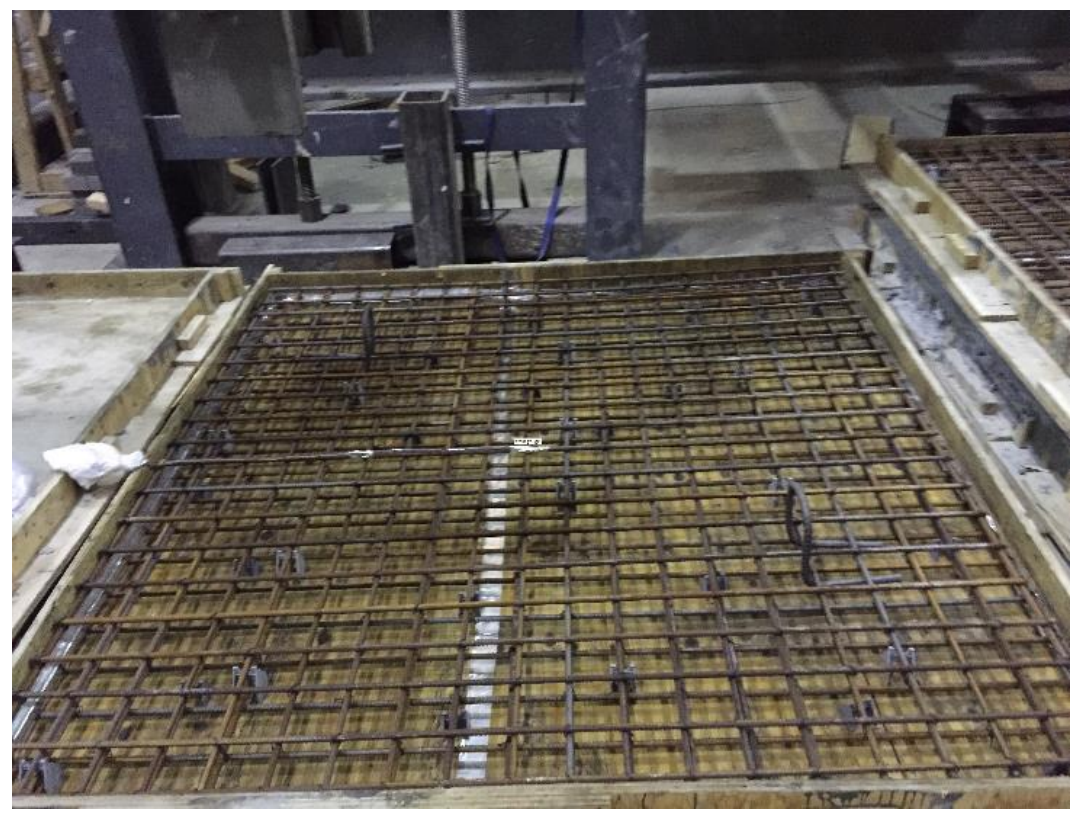

Fig. 3.4: Static specimen mold

\subsubsection{Test procedure}

Specimen was subjected to load at its midpoint and simply supported at its four corners. The applied load was upside down carried out using load cell $400 \mathrm{~mm}$ x $400 \mathrm{~mm}$ load area with maximum capacity of $250 \mathrm{kN}$. The load is applied in $5 \mathrm{kN}$ increments by means of a hydraulic jack. During testing, the slab was carefully inspected and cracks are marked at each load increment. The schematic diagram of the setup and the test configuration is illustrated in Fig. 3.5 and Fig. 3.6.

Deflection at the slab centers was measured with an LVDT gauge concentrated at upper face of the slab. Strain gauges are used to determine the magnitude and rate of strain in the steel reinforcement. One strain gauges are glued to the upper surface of main longitudinal reinforcement at the midpoint of specimen (Fig. 3.7).

Data acquisition system was used to record the applied load and the deflection at the midpoint of the slab. A hydraulic servo-controlled testing machine (MTS 815) is used to conduct the compression testing for the prisms. A hydraulic servo-controlled (MTS 793) testing machine, is used to preform tests for the static as low-speed loading rate ranges (Fig. 3.7). 


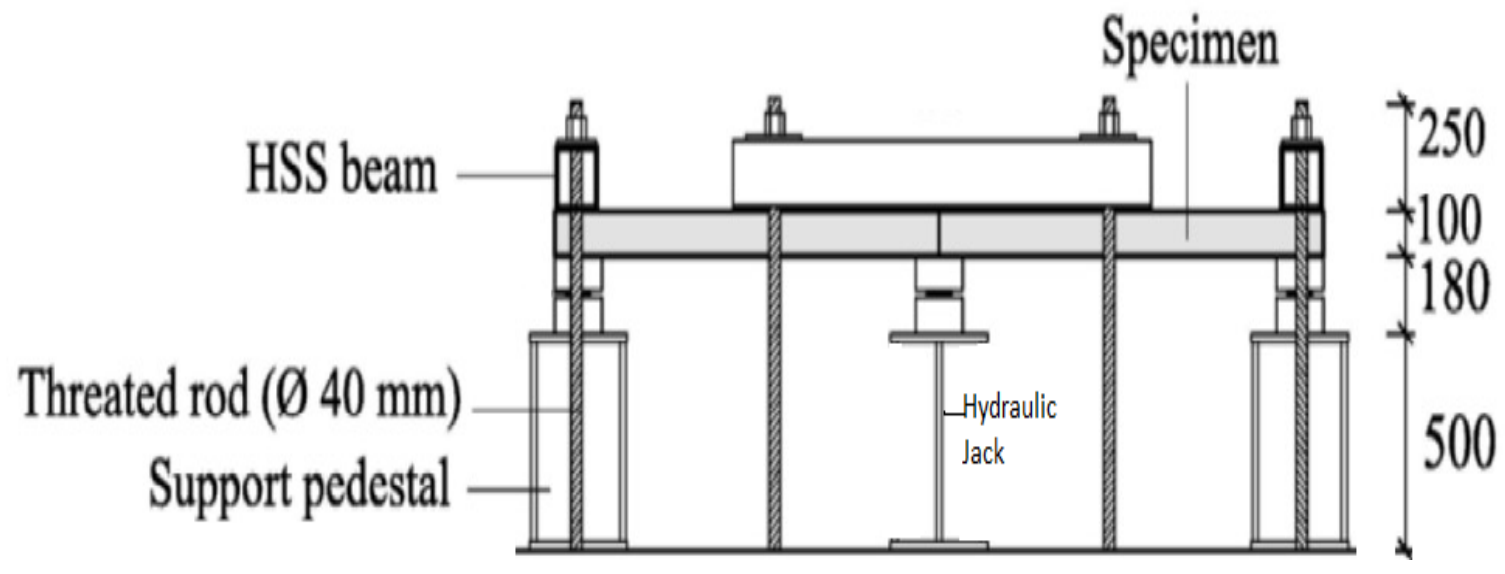

Fig. 3.5: Static Test setup

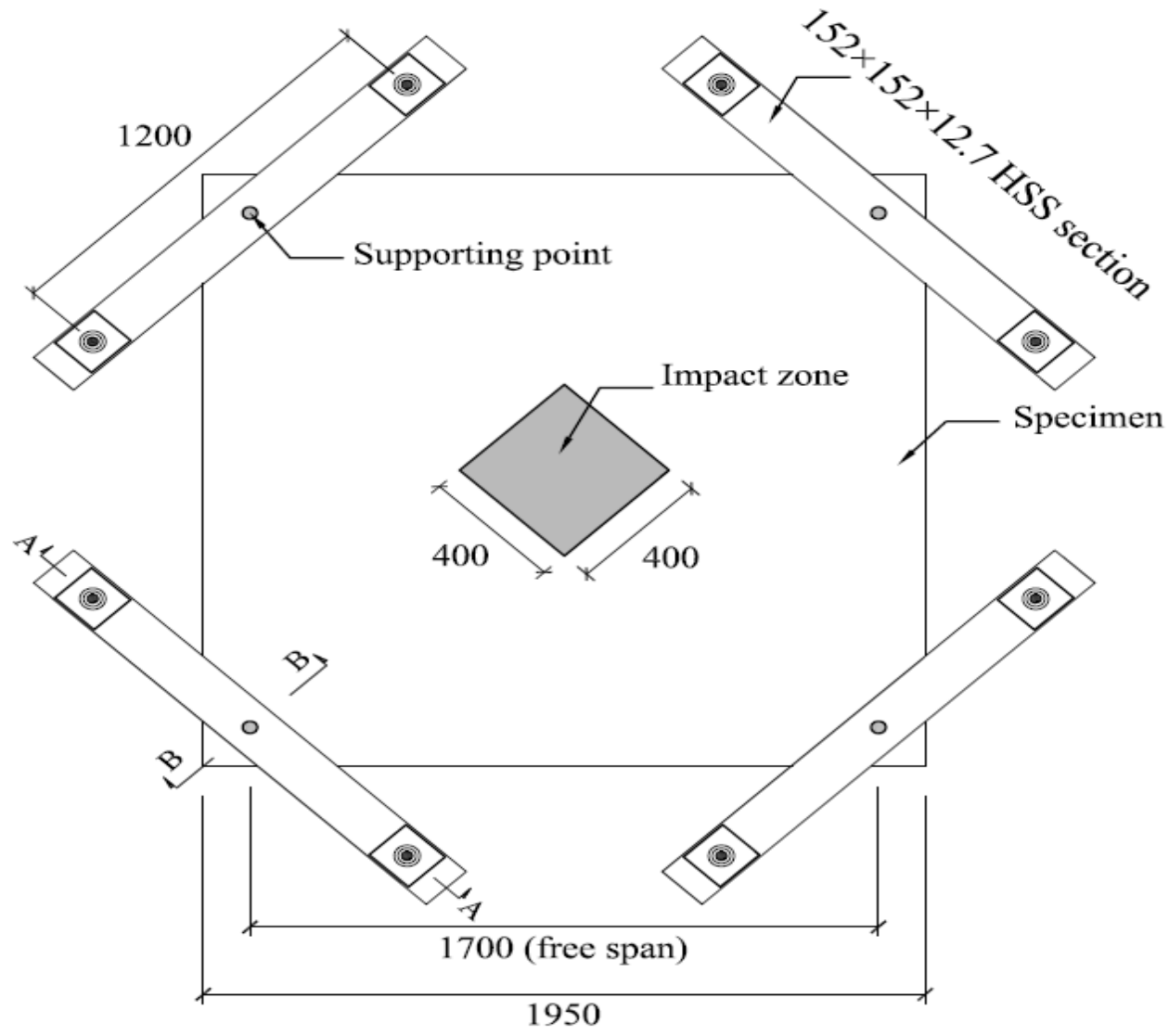

Fig. 3.6: Specimen setting layout 


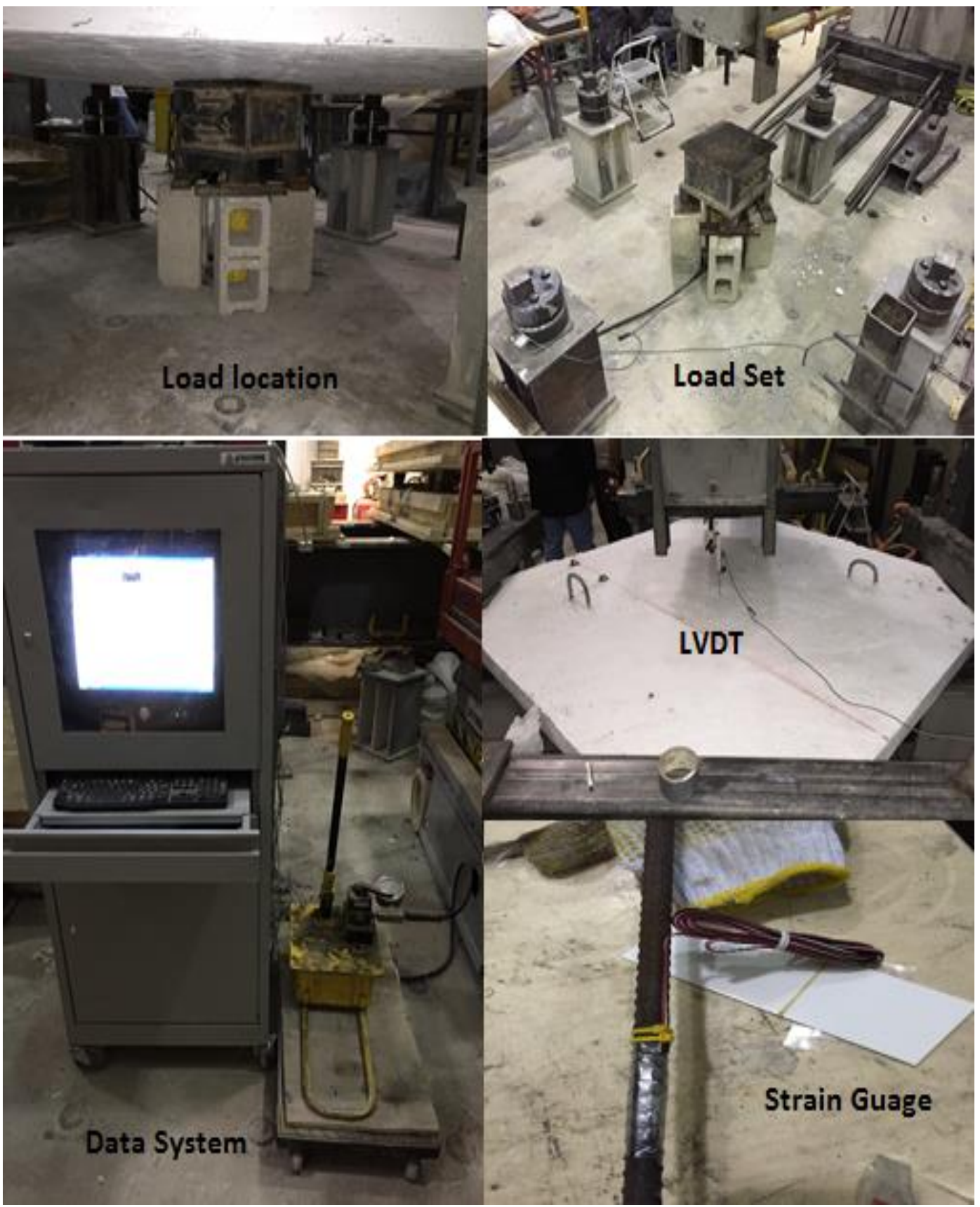

Fig. 3.7: Static test sensors and equipment

\subsection{Test result}

The data were recorded for slab including deflection, crack propagation at each load increment and steel strains. 


\subsubsection{Load - Deflection characteristics}

The load deflection curves were obtained using LVDT measurements at midpoint. The applied load versus the deflection at midpoint of the slab are shown in Fig. 3.8. The following Table. 3.2 shows the deflection at first crack, steel yield and ultimate load. The failure mode can be characterize as flexural failure. Stiffness $\mu$ is defined as the ratio of the ultimate load $p u$ to ultimate load deflection $\Delta u$.

$$
\mu=\frac{P u}{\Delta u}
$$

Where:-

$$
\begin{aligned}
& \mu=\text { Stiffness } \mathrm{kN} / \mathrm{mm} \\
& \mathrm{P}_{\mathrm{u}}=\text { Ultimate load } \mathrm{kN} \quad \Delta u=\text { Ultimate load deflection } \mathrm{mm}
\end{aligned}
$$

\begin{tabular}{|c|c|c|c|c|c|c|c|c|}
\hline Slab & $\begin{array}{c}\text { Concrete } \\
\text { Strength } \\
\mathrm{MPa}\end{array}$ & $\begin{array}{c}\text { Steel } \\
\text { ratio } \\
\%\end{array}$ & $\begin{array}{c}\text { First } \\
\text { Crack } \\
\text { load } \\
\text { kN }\end{array}$ & $\begin{array}{c}\text { First } \\
\text { Crack } \\
\text { deflection } \\
\text { mm }\end{array}$ & $\begin{array}{c}\text { Yield } \\
\text { load } \\
\text { kN }\end{array}$ & $\begin{array}{c}\text { Yield load } \\
\text { deflection } \\
\text { mm }\end{array}$ & $\begin{array}{c}\text { Ultimate } \\
\text { load } \\
\mathrm{kN}\end{array}$ & $\begin{array}{c}\text { Ultimate } \\
\text { load } \\
\text { deflection } \\
\text { mm }\end{array}$ \\
\hline NSC-S & 45 & $\overline{11}$ & 50 & 5.89 & 135 & 26.37 & 208.50 & 71.87 \\
\hline
\end{tabular}

Table. 3.2: Deflection characteristics of the test slab 


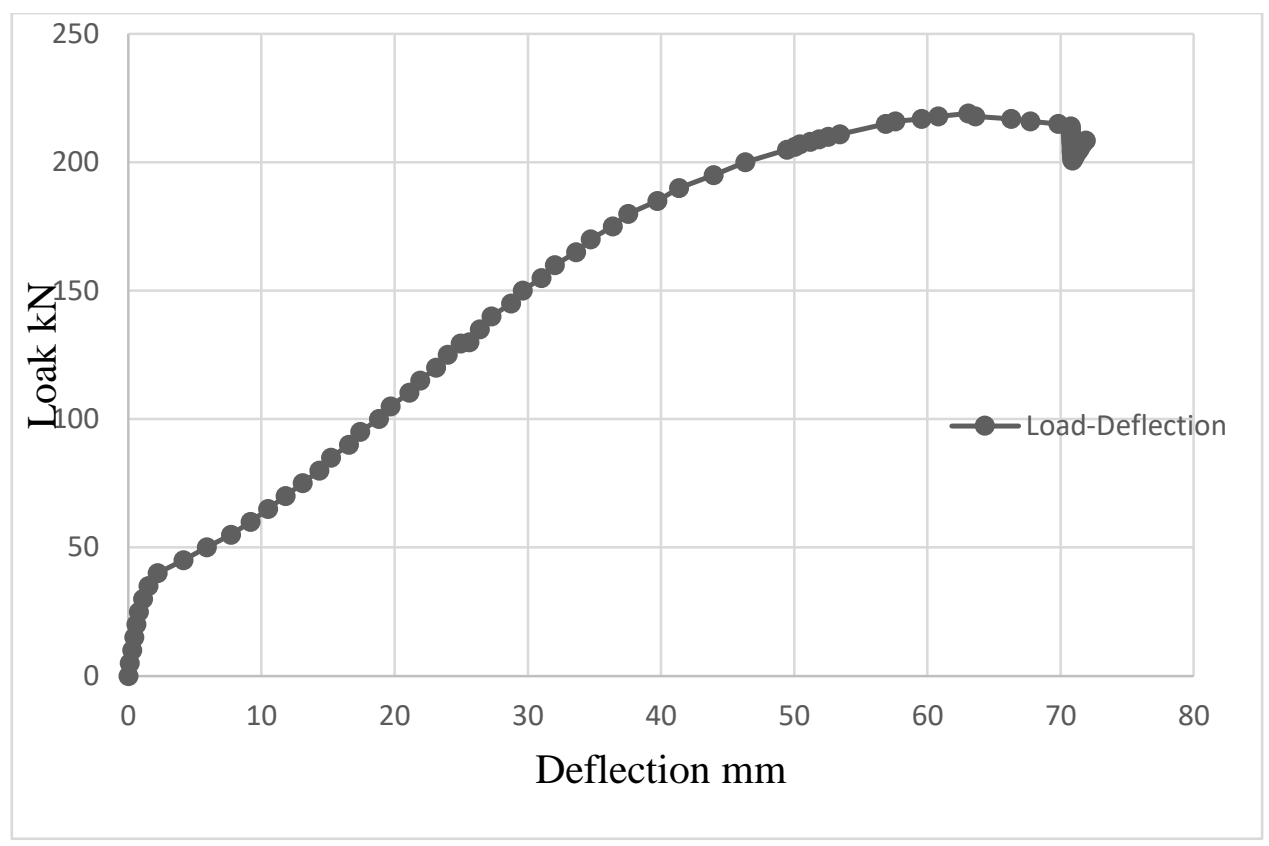

Fig. 3.8: Static Load vs Deflection curve

\subsubsection{Ductility and energy absorption characteristics}

Ductility $\mathrm{U}$ is defined as the ratio of the ultimate load deflection $\Delta u$ to yield load deflection $\Delta y$. The energy absorption capacity is the area under the load-deflection curve. Table 3.3 shows the result.

$$
\mathrm{U}=\frac{\Delta u}{\Delta y}
$$

Where:-

$\mathrm{U}=$ Ductility

$\Delta y=$ Yield load deflection $\mathrm{mm} \quad \Delta u=$ Ultimate load deflection $\mathrm{mm}$ 
Table. 3.3: Ductility, Stiffness, and Energy absorption

\begin{tabular}{|c|c|c|c|c|c|}
\hline Slab & $\begin{array}{l}\text { Concrete } \\
\text { strength } \\
\mathrm{MPa}\end{array}$ & $\begin{array}{c}\text { Steel ratio } \\
\%\end{array}$ & Ductility & $\begin{array}{l}\text { Stiffness } \\
\mathrm{kN} / \mathrm{mm}\end{array}$ & $\begin{array}{c}\text { Energy absorption } \\
\text { capacity } \\
\text { kN.mm x }\left(10^{3}\right)\end{array}$ \\
\hline NSC-S & 45 & 1 & 2.73 & 2.90 & 10.25 \\
\hline
\end{tabular}

\subsubsection{Steel strain}

Strain gauges are used to determine the magnitude and rate of strain in the steel reinforcement. One strain gauges are glued to the upper surface of main longitudinal reinforcement at the midpoint of specimen in one directions (Malvar and Crawford, 1998).

The stress strain curve (Fig. 3.9) obtained from the sensor indicate that the yield strain of a steel bar is about $2.0 \times 10^{3}$ associated with load $135 \mathrm{kN}$.

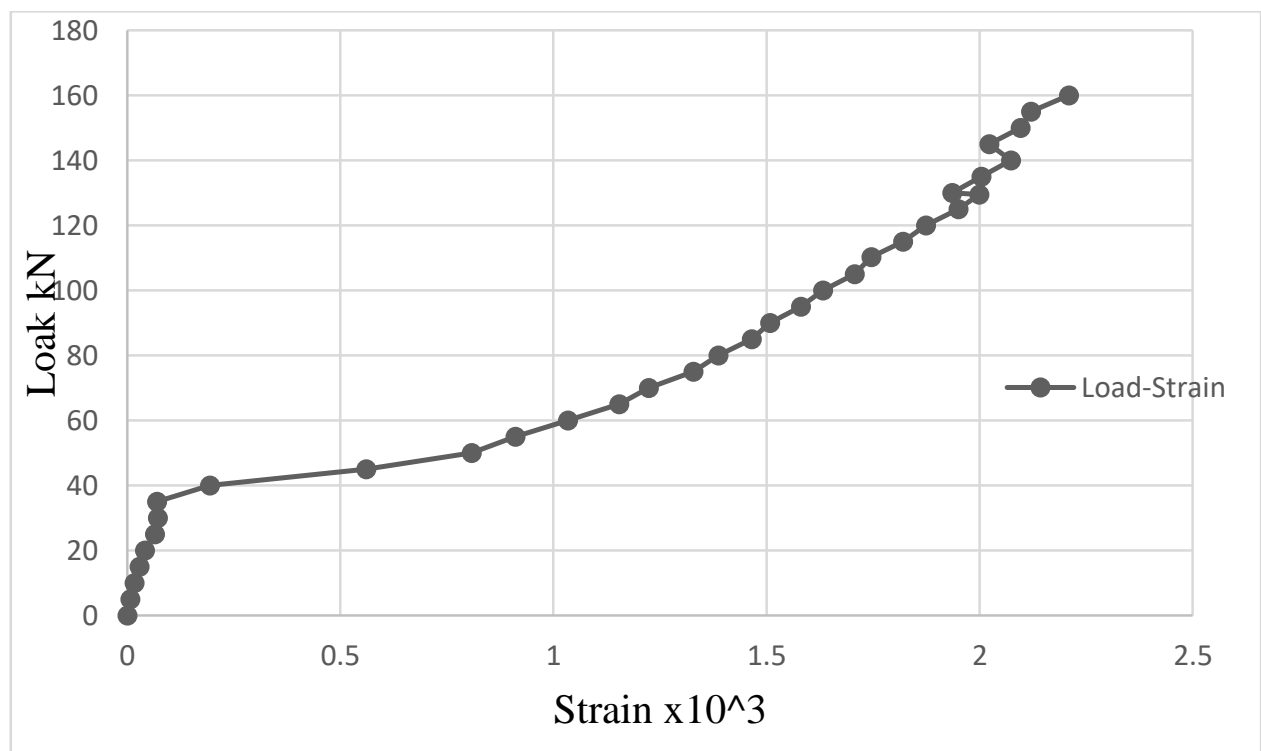

Fig. 3.9: Stress strain curve 


\subsubsection{Crack and failure mode}

The specimen typically failed in a flexural mode. Under the initial load, cracking patterns aligned with steel reinforcement grids are developed on top surface of the slab and no concrete scabbing.

The reinforcement yield before punching occurs and consequently the slab exhibits large deflection prior to failure. The slab reach the state of steadily increasing deflection at almost constant load, which is a normal characteristic for a reinforcement concrete fail in flexural. The crack configuration is illustrated in Fig. 3.10.

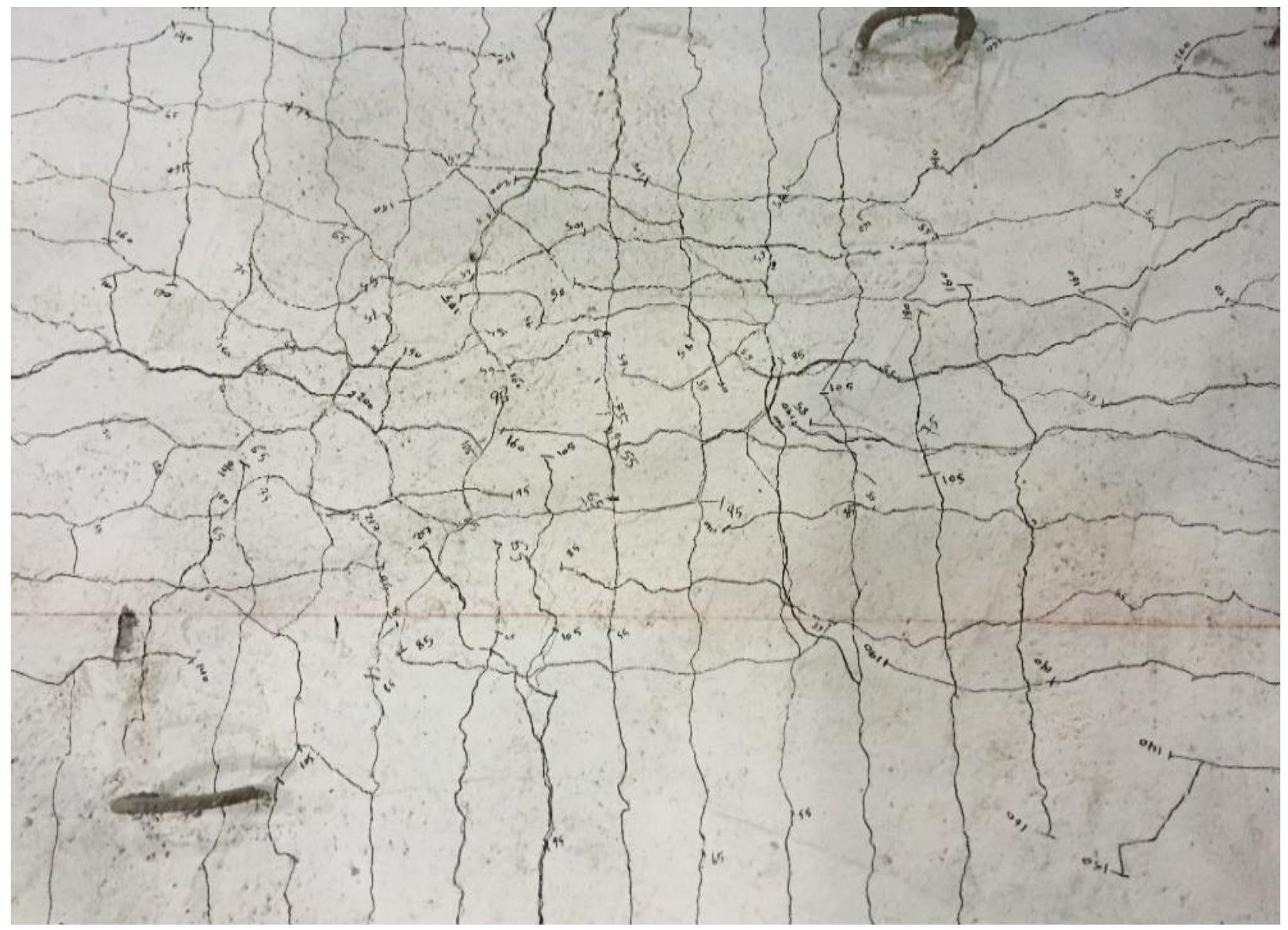

Fig. 3.10: Static Test Cracks Pattern 


\subsection{Theoretical result}

The experimental study was compared to the predicted values of punching strength computed Using CSA A23.3 (2014), ACI 318 (2011) and yield line flexural strength (Kennedy and Goodchild, 2004). The ratio of the observed strength prior to punching to that computed by the yield line flexural strength $\emptyset_{0}$ has been used to divide punching failures into shear if the value $\emptyset_{0}$ $\leq 1$ and flexure failure $\emptyset_{0} \geq 1$ which what was found in this study. A description of the studies summary in tables below. Tables $3.4-3.8$ summarize the results.

$$
\begin{aligned}
& \mathrm{P}_{\text {flex }}=\mathrm{K} \times \mathrm{M}_{\mathrm{b}} \\
& \emptyset_{0}=\mathrm{P}_{\mathrm{u}} / \mathrm{P}_{\text {flex }}
\end{aligned}
$$

Where:-

$M b=\mathrm{p} \times$ fy $\times \mathrm{d}^{2} \mathrm{x}(1-0.59(\mathrm{pfy} / \mathrm{fc}))$

$\mathrm{K}=4$ from support conditions

$\mathrm{P}_{\mathrm{u}}=$ Experimental

$$
\mathrm{P}_{\mathrm{CSA}}=\mathrm{Vr}_{\text {mim }} \mathrm{x} \text { Area }
$$

Where:-

$\mathrm{Vr}_{\text {mim }}=$ the minimum of $\mathrm{V}_{1}, \mathrm{~V}_{2}, \mathrm{~V}_{3}$.

$$
\begin{array}{ll}
\operatorname{Vr}_{1}=\left(1+2 / \beta_{\mathrm{c}}\right) \times 0.19 \lambda \varphi_{\mathrm{c}}\left(\mathrm{f}_{\mathrm{c}}^{0.5}\right) & \lambda=1 \text { for NSC } \quad \varphi_{\mathrm{c}}=0.65 \\
\operatorname{Vr}_{2}=\left(0.19+\left(\alpha_{\mathrm{s}} \mathrm{d} / \mathrm{b}_{0}\right)\right) \times \lambda \times \varphi_{\mathrm{c} \times} \times\left(\mathrm{f}_{\mathrm{c}}^{0.5}\right) & \alpha_{\mathrm{s}}=3 \text { for edge column } \quad \beta_{\mathrm{c}}=1 \\
\operatorname{Vr}_{3}=0.38 \times\left(\mathrm{f}_{\mathrm{c}}^{0.5}\right) \times \lambda \times \varphi_{\mathrm{c}} & \mathrm{b}_{0}=2 \times \text { (load side } 1+\text { load side } 2+(2 \times \mathrm{d})
\end{array}
$$

$$
\mathrm{P}_{\mathrm{ACI}}=\mathrm{Vc}_{\operatorname{mim}} \mathrm{x} \text { Area }
$$

Where:-

$\mathrm{V}_{\text {mim }}=$ the minimum of $\mathrm{V}_{1}, \mathrm{~V}_{2}, \mathrm{~V}_{3}$.

$\mathrm{Vc}_{1}=0.17\left(1+2 / \beta_{\mathrm{c}}\right) \times \lambda \times\left(\mathrm{f}_{\mathrm{c}}^{0.5}\right) \quad \beta_{\mathrm{c}}=1$, Support (large side /short side)

$\mathrm{Vc}_{2}=0.083\left(2+\left(\alpha_{\mathrm{s}} \mathrm{d} / \mathrm{b}_{0}\right)\right) \times \lambda \times\left(\mathrm{f}_{\mathrm{c}}{ }^{0.5}\right) \quad \alpha_{\mathrm{s}}=30$ for edge column

$\mathrm{Vc}_{3}=0.33 \times\left(\mathrm{f}_{\mathrm{c}}^{0.5}\right) \times \lambda \quad \lambda=1$ for NSC 
Table. 3.4: specimen parameter

\begin{tabular}{|c|c|c|c|c|c|c|c|c|}
\hline Slab & $\begin{array}{c}\text { Slab } \\
\text { side mm }\end{array}$ & $\begin{array}{c}\text { Support } \\
\text { dimension } \\
\mathrm{mm}\end{array}$ & $\begin{array}{l}\text { Load plat } \\
\text { dimension } \\
\mathrm{mm}\end{array}$ & $\begin{array}{c}\text { Effective } \\
\text { depth } \\
\text { mm }\end{array}$ & $\begin{array}{c}\text { Steel } \\
\text { yield } \\
\text { strength } \\
\mathrm{MPa}\end{array}$ & $\begin{array}{c}\text { Concrete } \\
\text { strength } \\
\mathrm{MPa}\end{array}$ & $\begin{array}{c}\text { Steel } \\
\text { ratio } \\
\%\end{array}$ & $\begin{array}{c}\text { length of } \\
\text { the } \\
\text { control } \\
\text { perimeter } \\
\text { mm }\end{array}$ \\
\hline NSC-S & 1,950 & 1,700 & 400 & 75 & 433.4 & 45 & $\bar{~} 1$ & $1,1,900$ \\
\hline
\end{tabular}

Table. 3.5: Comparison of yield line method with experimental result

\begin{tabular}{c|c|c|c|c|c}
\hline \hline $\begin{array}{c}\text { Yield line } \\
\text { Flexural }\end{array}$ & $\mathrm{K}$ & $\mathrm{M}_{\mathrm{b}} \mathrm{kN}$ & $\mathrm{P}_{\text {flex }} \mathrm{kN}$ & $\mathrm{P}_{\mathrm{u}} \mathrm{kN}$ & $\emptyset_{0}$ \\
\cline { 2 - 6 } & 4 & 43.22 & 172.87 & 208.50 & 1.21 \\
\hline \hline
\end{tabular}

Table. 3.6: CSA A23.3-04 code result

\begin{tabular}{c|c|c}
\hline \hline \multicolumn{3}{|c|}{ CSA A23.3-04 } \\
\hline \hline $\mathrm{Vr}_{1} \mathrm{MPa}$ & $\mathrm{Vr}_{2} \mathrm{MPa}$ & $\mathrm{Vr}_{3} \mathrm{MPa}$ \\
\hline \hline 2.49 & $\mathbf{1 . 3 4}$ & 1.66 \\
\hline \hline \multicolumn{2}{|c}{} \\
\hline \hline $\mathrm{Vr}_{\min } \mathrm{MPa}$ & $\mathrm{A} \mathrm{mm}$ & $\mathrm{P}_{\mathrm{th}} \mathrm{kN}$ \\
\hline \hline $\mathbf{1 . 3 4}$ & 160000 & 215.17 \\
\hline \hline
\end{tabular}

Table. 3.7: ACI 318-11 Code result

\begin{tabular}{c|c|c}
\hline \hline \multicolumn{3}{|c|}{ ACI 318-11 } \\
\hline \hline $\mathrm{Vc}_{1} \mathrm{MPa}$ & $\mathrm{Vc}_{2} \mathrm{MPa}$ & $\mathrm{Vc}_{3} \mathrm{MPa}$ \\
\hline \hline 3.42 & $\mathbf{1 . 7 7}$ & 2.21 \\
\hline \hline \multicolumn{3}{|c}{} \\
\hline \hline $\mathrm{Vc}_{\min } \mathrm{MPa}$ & $\mathrm{A} \mathrm{mm}$ & $\mathrm{P}_{\text {th }} \mathrm{kN}$ \\
\hline \hline $\mathbf{1 . 7 7}$ & 160000 & 283.67 \\
\hline \hline
\end{tabular}

Table. 3.8: Comparison of CSA and ACI codes with test result

\begin{tabular}{c|c|c|c}
\hline \hline \multirow{2}{*}{ CSA A23.3-04 } & $\mathrm{P}_{\text {th } \mathrm{kN}}$ & $\mathrm{P}_{\mathrm{u}} \mathrm{kN}$ & Ratio \\
\cline { 2 - 4 } & 215.17 & 208.50 & 0.97 \\
\hline \hline \multirow{2}{*}{ ACI 318-11 } & $\mathrm{P}_{\text {th } \mathrm{kN}}$ & $\mathrm{P}_{\mathrm{u}} \mathrm{kN}$ & Ratio \\
\cline { 2 - 4 } & 283.67 & 208.50 & 0.74 \\
\hline \hline
\end{tabular}




\subsection{Discussion of the static results}

The load deflection curves can be represented by two straight lines with different slopes. The first line has a slope corresponding to the stiffness of the un-cracked slab can reach up to $0.24 \mathrm{P}_{\mathrm{u}}$ (First Crack load), while the second line corresponding to the $\mu$ stiffness of the cracked slab and its approximately $1 / 4$ of the first line.

The stress strain curve (Fig. 3.9) revealed that the tension reinforcement yielded before punching took place which lead to flexural failure took place in slab.

The crack pattern (Fig 3.10) indicates that flexural bending cracks are developed. Moreover, the slab exhibit high deformation prior the punching occur that indicate the specimen typically failed in a ductile punching shear "flexural mode".

The analytical result revealed that, the yield line underestimate the punching load by $21 \%$, While the CSA code overestimate the punching load by $3 \%$ and ACI code overestimate the punching load by $26 \%$. Then, use of CSA A23.3 (2014) code to predict the slab failure mode is little more accurate than yield line method and ACI 318 (2011) code. 


\section{CHAPTER 4}

DYNAMIC LOAD TEST 


\section{DYNAMIC LOAD TEST}

\subsection{Introduction}

Recently, it has been a growing trend to design some structures to resist both static and low velocity impact loads. Low velocity high mass impact loading conditions with velocities up to $10 \mathrm{~m} / \mathrm{s}$ are the common impact scenarios for civil engineering. Typical low velocity impact scenarios include transportation structures subjected to vehicle collisions, airport runway platforms during aircraft landing, and offshore structures subjected to ice and/or ship impact. Additionally, dynamic loading arising from natural hazards such as tornadoes and earthquakes are also related to low velocity impact.

Experimental investigations on the dynamic response of NSC structural members (i.e. beams and slabs) are limited. Additionally, Most of available data are related to extreme loading conditions such as blast loading and high velocity impact simulation (Li et al., 2005).

Reinforced Concrete (RC) member subjected to impact loading is a design concept that has not yet been fully developed. Moreover, current design codes did not suggest a clear method to analyze and predict possible failure mode for RC slabs under impact (Tahmasebinia and Remennikov, 2008). The characteristics of impact loading are different from those of static loading. Since the duration of loading is very short, the effect of strain rate becomes significantly higher than that under quasi-static. As a result, structural response and failure modes will be different (Chen and May, 2009).

There is no standard test technique to assess the impact resistance of concrete members. ACI Committee 544 (1988) proposed a repeated drop-weight impact test for testing FRC materials, in which the number of drops necessary to cause prescribed levels of damage in the specimen is the main parameter and the drop-height is kept constant. Relative impact resistance of specimen can be evaluated using this technique.

In general, low-velocity impact is relevant to most common dynamic accidental loading cases in civil engineering structures (CEB-FIP, 1988). Low-velocity impact tests are commonly based on large mass low-velocity technique using the potential energy method to generate the impact energy. Examples of such setups include falling drop-weight and pendulum-type. 


\subsection{Testing methods for concrete slab under Dynamic load}

This test presents the details of a well-organized and equipped experimental, aiming to study the dynamic behaviors with regard to the deformation and strength characteristic of NSC slab. The following sections summarize the processes required to perform the tasks:

\subsubsection{Experimental work}

NSC-D: It is an abbreviation stand for Normal Strength Concrete slab under dynamic testing. One double reinforced NSC slab $1950 \mathrm{~mm}$ square $100 \mathrm{~mm}$ thickness with 1.0\% CSA standards Grade 400 deformed steel bars size of $10 \mathrm{M}$ formed as double steel gage spacing $100 \mathrm{~mm}$. The concrete mix used in this study is NSC with target 28-day cylinder compressive strength of $45 \mathrm{MPa}$. The bottom steel rebar represent the main reinforcement for the specimen. The content of the experimental techniques is summarized from reference (Othman and Marzouk, 2015) in references section.

The drop-weight low velocity impact setup has been designed and fabricated at structural laboratory of Ryerson University. The system is capable of dropping $475 \mathrm{~kg}$ mass from a height $4.15 \mathrm{~m}$ with a capacity of $19.24 \mathrm{~kJ}$ with impact velocity of $9 \mathrm{~m} / \mathrm{s}$. The impact setup is equipped with sophisticated instrumentation to measure impact force, reaction forces, and the specimen displacements.

The drop weight is elevated to a desired height above specimens using an electromagnetic hoist model CER-7 with a capacity of $600 \mathrm{~kg}$ and then the mass is released by switching off the magnet to hard impact generate a velocity that depends on the dropping height. A tower frame with four vertical steel tracks is used to guide the drop-weight and to ensure hitting specimens' at the specified point. The guiding frames are mounted to the strong $1 \mathrm{~m}$ thick reaction wall of the structural laboratory. The steel tracks of the tower are lined with grease to reduce any possible friction.

Two plain elastomeric rubber pads with thickness of $15 \mathrm{~mm}$ are used at each slab corner. One elastomeric pad between the top surface of specimen and the HSS section, while the other between the bottom surface of specimen and the support. They absorb the vibration results from impact and minimize the quantity of noise in the acquired data (Zineddin and Krauthammerr, 2007). 
Two accelerometers with maximum capacity of 20,000 $\mathrm{g}$ and 5,000 $\mathrm{g}$ are mounted to the dropweight to determine the impact force excited in the falling drop-weight. One steel strain gauge been attached to the middle rebar in the tension part of the slab (lower portion) to determine the magnitude and rate of strain in the steel reinforcement.

In order to measure the support reaction force, four quartz dynamic load cells where used with a capacity of $650 \mathrm{kN}$. Two contacts-less laser KEYENCE (model IL-300) sensors are used to measure displacements. Raw acquired data are recorded using a digital dynamic data acquisition system ECON (model MI-7008).

\subsubsection{Test data filtering}

The accelerometers data are filtered using low-pass second order Butterworth filter. The filter is applied using 'filtfilt' command built-in MATLAB that is a forward-backward filtering algorithm. i.e. does not shift the time phase (MathWorks, 2011). An approximate value of the peak acceleration value of $2490 \mathrm{~m} / \mathrm{s}^{2}$ or $254 \mathrm{~g}$ 's can be obtained by simply computing the maximum slope of the velocity curve shown in Fig 4.1. The filtered accelerations is integrated to obtain the corresponding velocity responses. The filtered acceleration response resulting from the $2.5 \mathrm{kHz}$ cutoff is selected (Fig. 4.2).
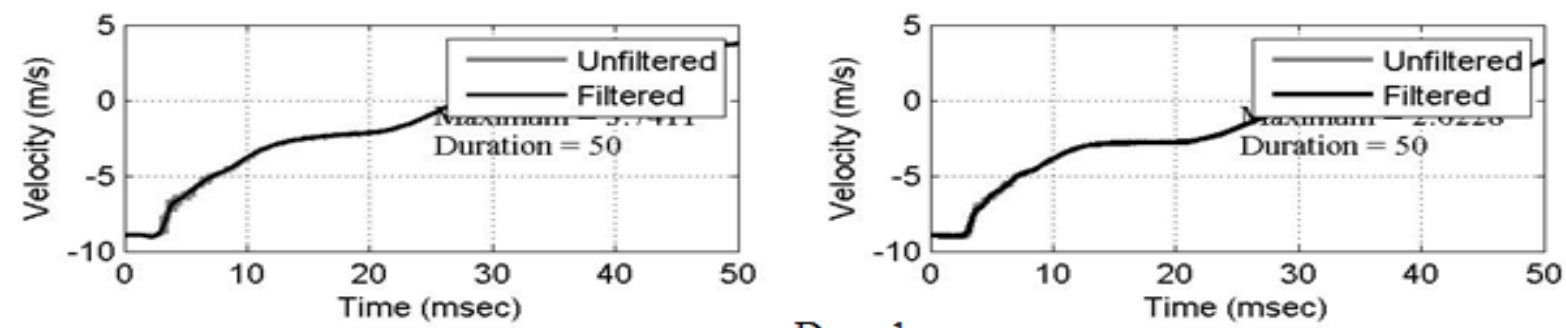

Drop 1
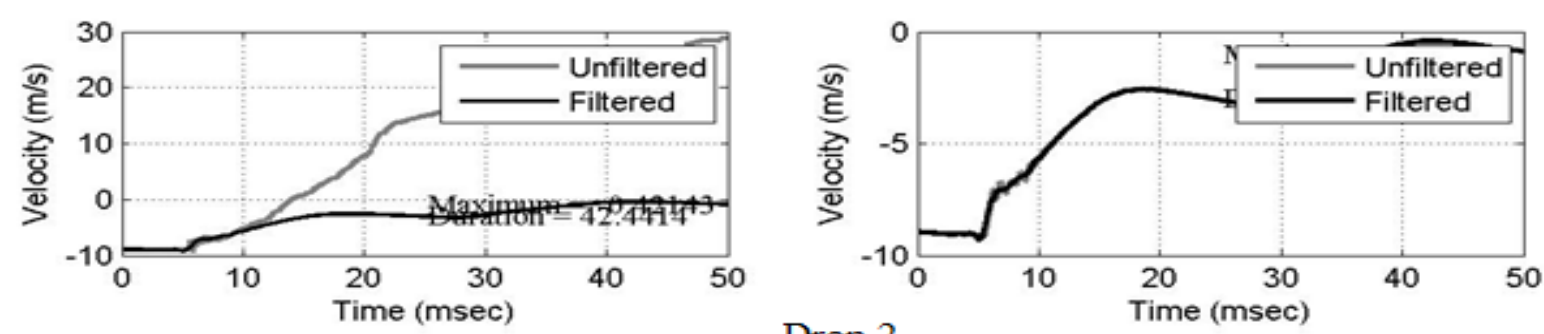

Drop 2

Fig. 4.1: Velocity - Time histories data 

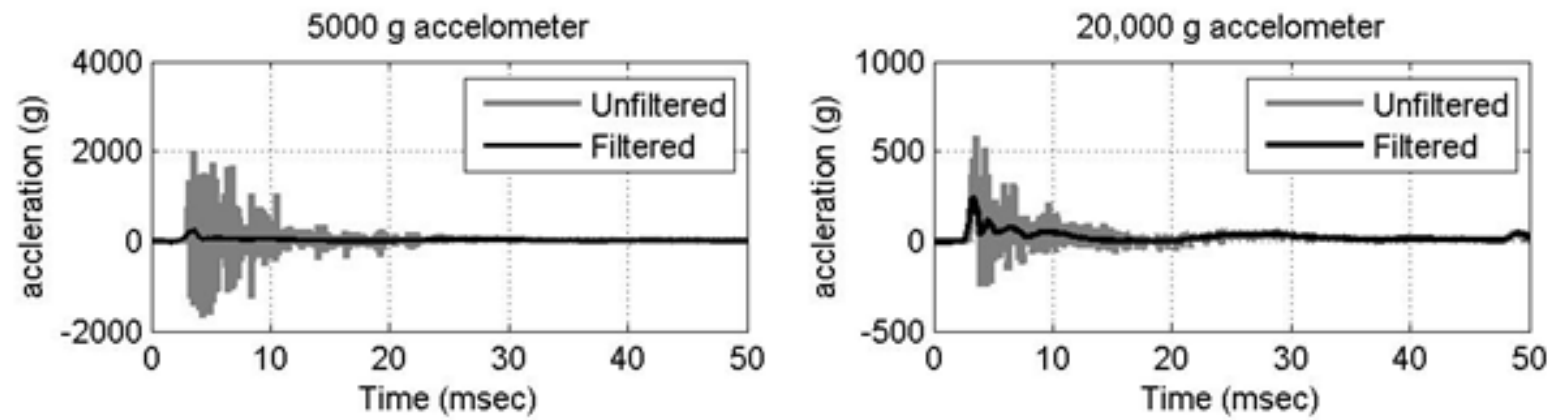

Drop 1
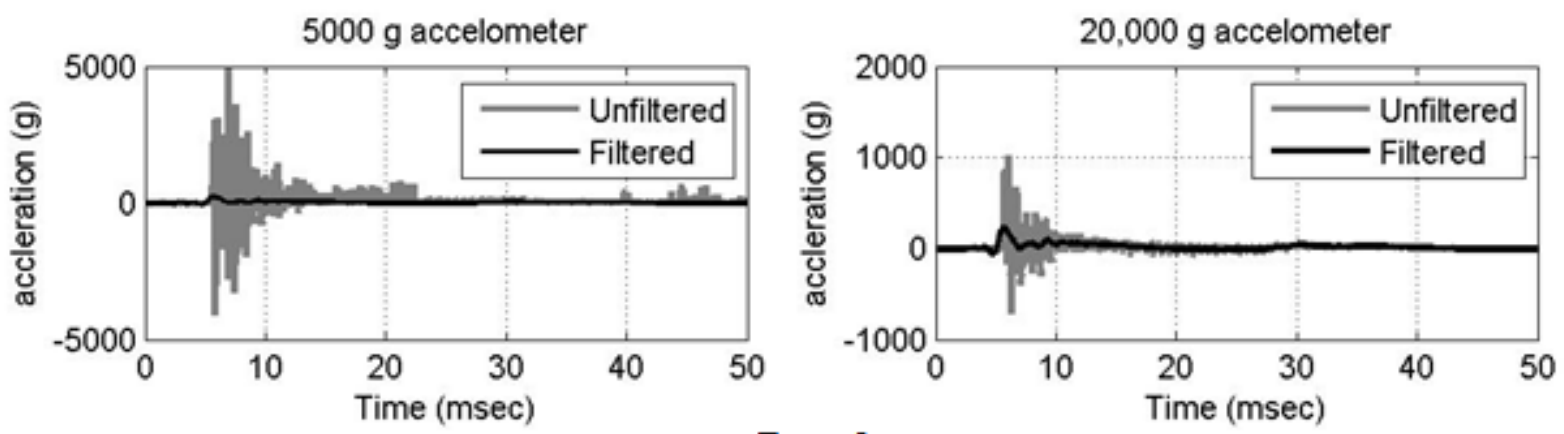

Drop 2

Fig. 4.2: Acceleration - Time histories data

\subsection{Experimental program}

\subsubsection{Materials}

The concrete mix used in this study is NSC with target 28-day cylinder compressive strength of $45 \mathrm{MPa}$. This matrix includes ordinary Portland cement, quartzite sandstone, and crushed granite of $14 \mathrm{~mm}$ maximum nominal size. This matrix is ready mix concrete provided by local contractor. The specimen cast using single concrete batch; then cured under moist plastic cover for 7 days. Then, the specimen move out of it molds and placed to dry in laboratory air conditions until testing at the age of 28 days. $10 \mathrm{M}$ - CSA standard Grade $400 \mathrm{MPa}$ steel rebar are used as longitudinal reinforcement. This matrix is based on the composition developed by Marzouk (1991). The materials properties are tested and summarized in Table 4.1. 
Table. 4.1: Properties of NSC and Steel

\begin{tabular}{l|c}
\hline \hline \multicolumn{2}{|c|}{ Normal Strength Concrete } \\
\hline \hline Density $\left(\mathrm{kg} / \mathrm{m}^{3}\right)$ & 2400 \\
\hline Compressive strength f'c (MPa) & 45 \\
\hline Flexural strength (MPa) & 5 \\
\hline Elastic Modulus Ec (GPa) & 30.951 \\
\hline \hline \multicolumn{1}{c}{ Steel reinforcement } \\
\hline \hline Bar size & $10 \mathrm{M}$ \\
\hline Diameter $(\mathrm{mm})$ & 11.29 \\
\hline Mass $(\mathrm{kg} / \mathrm{m})$ & 0.775 \\
\hline Yield stress fy (MPa) & 433.4 \\
\hline Yield strain $\varepsilon_{\mathrm{y}}$ & $2.0 \times 10^{-3}$ \\
\hline Ultimate strength fult $(\mathrm{MPa})$ & 621.7 \\
\hline Elastic Modulus Es $(\mathrm{GPa})$ & 201.1 \\
\hline$-\cdots$
\end{tabular}

\subsubsection{Specimen}

The test specimen was simply supported in all four corner. The slab was $1,950 \mathrm{~mm}$ square with a thickness of $100 \mathrm{~mm}$. A steel reinforcement of $1.0 \%$ size $10 \mathrm{M}$ double steel gage spacing $100 \mathrm{~mm}$ were used for top and bottom reinforcement. Six prisms of dimensions $100 \mathrm{~mm}$ x $100 \mathrm{~mm}$ x 400 $\mathrm{mm}$ leading to flexure test for the mix. Six cylinders of dimensions $100 \mathrm{~mm}$ x $200 \mathrm{~mm}$ leading to compression test for mix. The load had to be applied as uniformly. Both loading faces are grinded before testing (ASTM C39, 2001). Details of the specimen is given in Table 4.2. Typical dimensions and reinforcement layout of plate is shown in Fig. 4.3 and Fig 4.4. A typical specimen was used in static load test, the specimens collapse in flexural mode under mid-point static loading condition. 


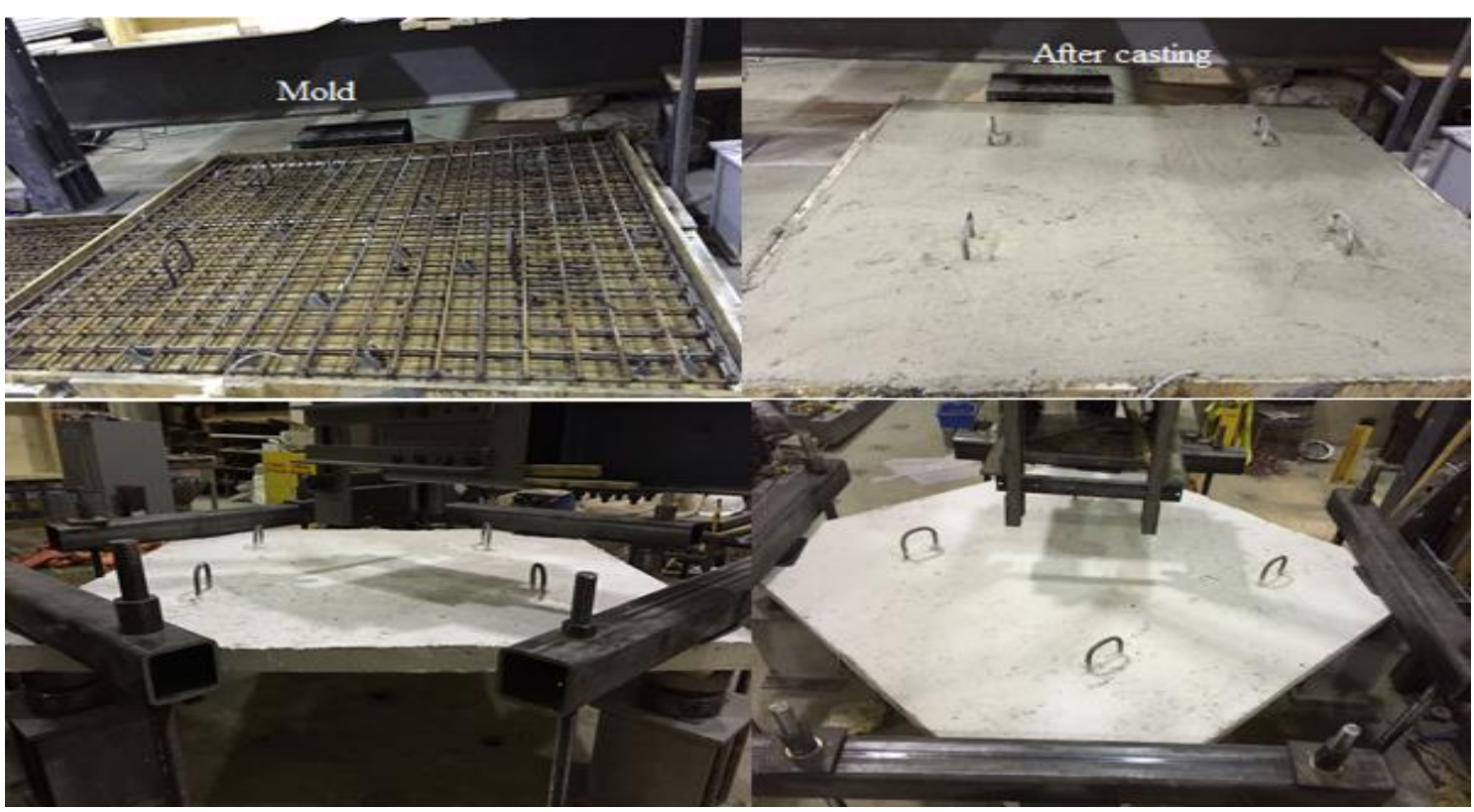

Fig. 4.3: Dynamic specimen mold

Table. 4.2: Details of the dynamic test specimen

\begin{tabular}{|c|c|c|c|c|c|c|c|}
\hline Slab & $\begin{array}{c}\text { Compressive } \\
\text { strength } \\
\text { MPA }\end{array}$ & $\begin{array}{l}\text { Bar } \\
\text { size }\end{array}$ & $\begin{array}{c}\text { Bar } \\
\text { spacing } \\
\text { mm }\end{array}$ & $\begin{array}{c}\text { Slab } \\
\text { thickness } \\
\text { mm }\end{array}$ & $\begin{array}{c}\text { Concrete } \\
\text { cover } \\
\mathrm{mm}\end{array}$ & $\begin{array}{c}\text { Average } \\
\text { depth } \\
\text { mm }\end{array}$ & $\begin{array}{c}\text { Steel } \\
\text { ratio } \\
\%\end{array}$ \\
\hline NSC-D & 45 & M 10 & 100 & 100 & 15 & 75 & 1 \\
\hline
\end{tabular}
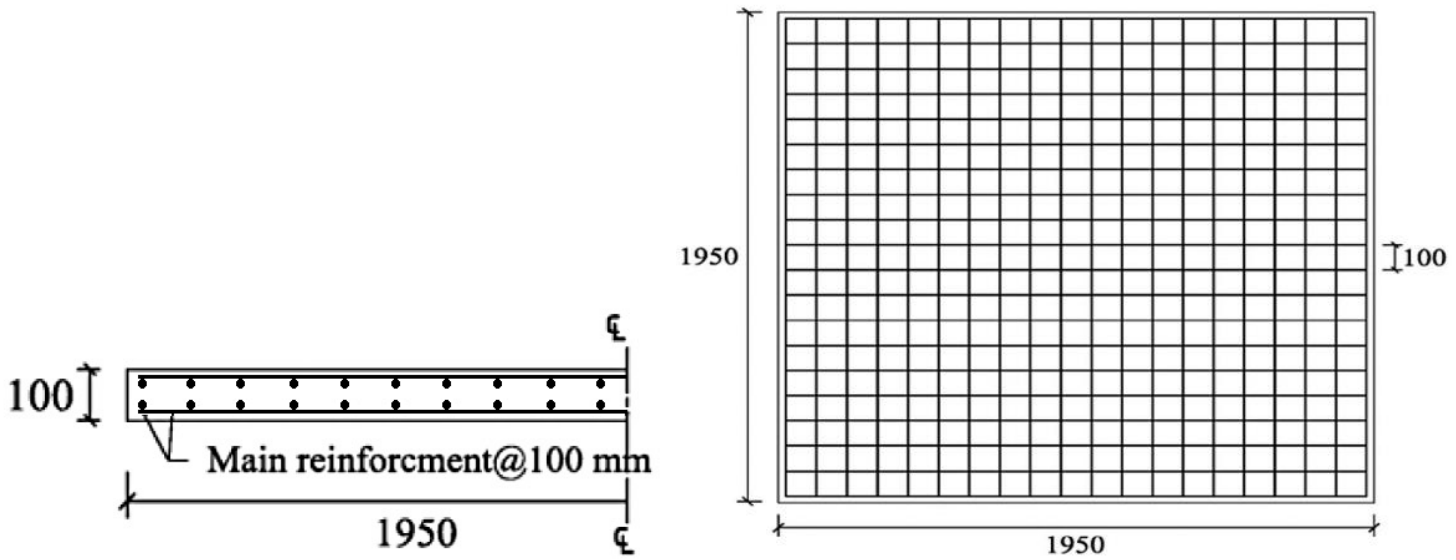

Fig. 4.4: Reinforcement details of the specimen 


\subsubsection{Test procedure}

Specimen was subjected to drop weight low-velocity load at its midpoint and simply supported at its four corners. Schematic diagram of the drop-weight impact test setup and supporting condition is illustrated in Fig. 4.5. The drop-weight impact frame system has been designed to generate a free-fall impact condition with a target capacity of $19.24 \mathrm{~kJ}$. The use of corner supports is selected to reduce the measurement of the reaction forces at corners. A tower frame with four vertical steel tracks is used to guide the mass in order to ensure hitting the specimens' mid-point.

Two impact drops are applied to specimen by dropping $475 \mathrm{~kg}$ weight from a height of $4.15 \mathrm{~m}$, resulting $9 \mathrm{~m} / \mathrm{s}$ theoretical impact velocity. The striking surface is flat and smooth with dimensions of $400 \mathrm{~mm} \times 400 \mathrm{~mm}$. The drop-weight is lifted to the height using an electrical crane. An electromagnet with a capacity of $600 \mathrm{~kg}$ (Fig. 4.5) attached to the crane is used to release the drop weight by switching off the magnet. The uplift of each corner is prevented using a special tie-down steel frame anchored at both ends to the strong floor of the Laboratory (Fig. 4.3).

The impact force excited in the falling steel weight is determined from Newton's 2nd law using the average reading of two $(20,000 \mathrm{~g}$ and 5,000 g) accelerometers mounted to the drop-weight. The reaction forces are measured using four dynamic-quartz load cells model 9081A manufactured by Kistler Instrument Corporation with a capacity of $650 \mathrm{kN}$. The mid-point displacement is measured using KEYENCE model IL-300 contact-less laser displacement sensor. A strain gauge glued to the bottom surface of main longitudinal reinforcement at the mid-point of specimens used to determine the magnitude and rate of strain in the steel reinforcement. A digital dynamic data acquisition system ECON model MI-7008 is used for data record and analysis (Fig. 4.6).

After testing, all specimens are visually inspected and crack patterns developed on the surfaces of specimens are marked.

Accelerometers data are filtered using low-pass second order and Butterworth filter is used with a cut-off frequency of $2.5 \mathrm{kHz}$. More details regarding the impact setup, used instrumentation, and accelerometers data filtering can be found in the literature review and reference (Othman and Marzouk, 2016). 

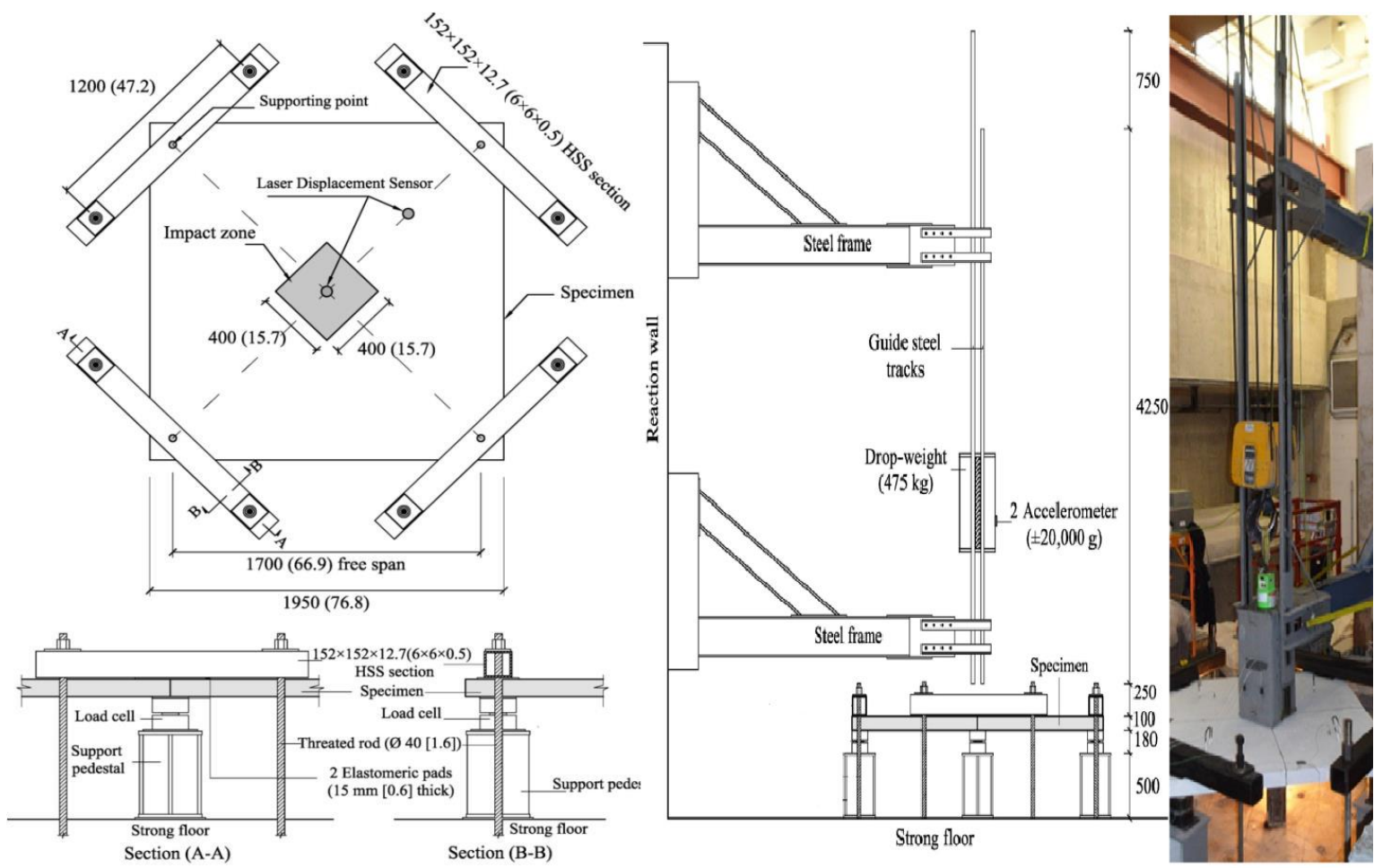

Fig. 4.5: Dynamic test setup

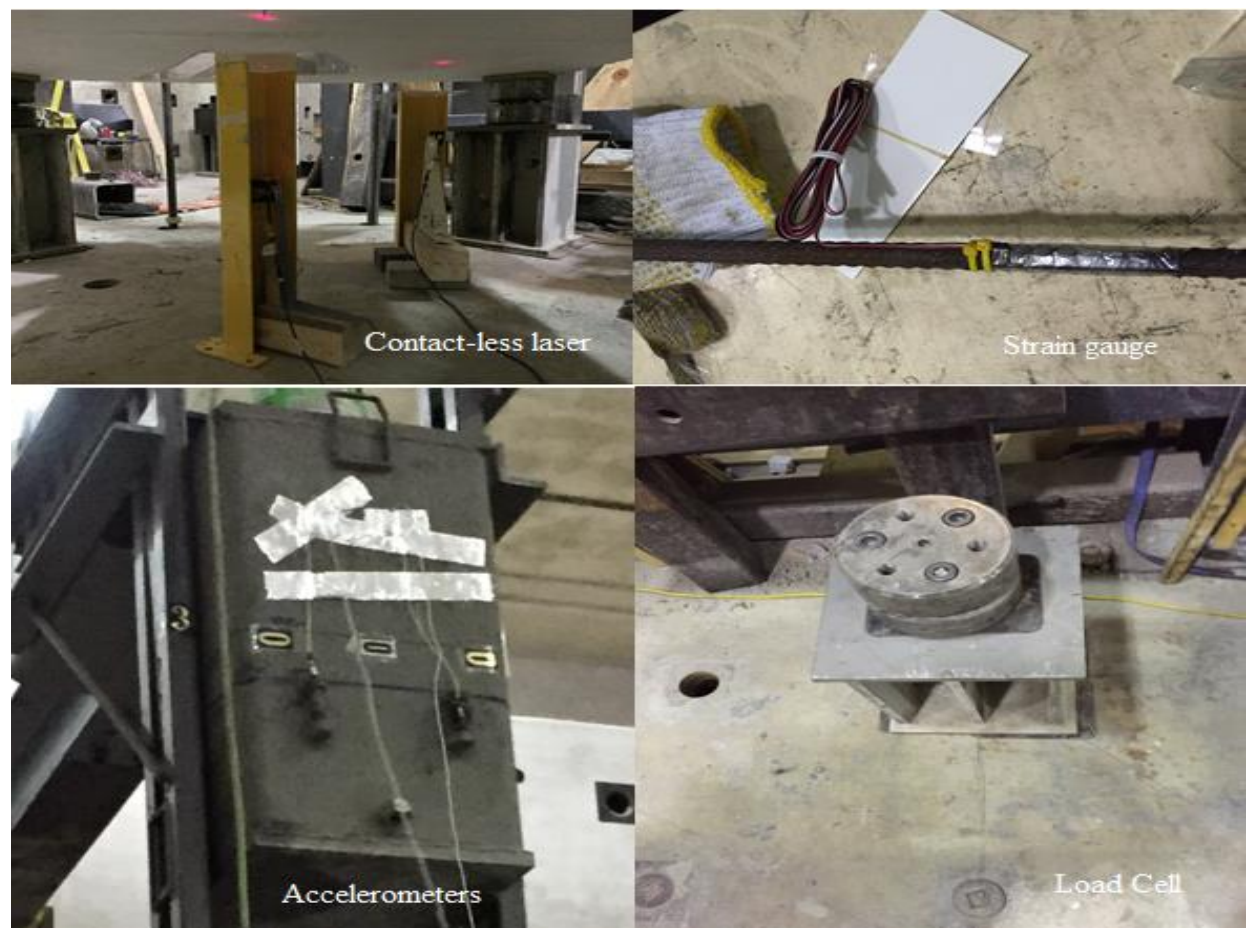

Fig. 4.6: Dynamic test sensors 


\subsubsection{Test termination criteria}

The impact testing was terminated when a severe punching damage took place with high probability of instrumentation damage.

\subsection{Test result}

The data are recorded for slab including Impact force with corresponding reaction force, midpoint displacement, crack propagation at each drop and steel strains. Table 4.3 reports the peak measurements and the corresponding time of conducted impact experiments. Impact force is determined using the average reading of two $(20,000 \mathrm{~g}$ and 5,000 $\mathrm{g})$ accelerometers mounted to the drop-weight. The reported peak reaction is the maximum total reaction force determined by multiply the summing the measurements of two load cells with two since reaction force responses from load cells at the four corner supports are typically similar in terms of magnitude and time response. The peak steel strain determined using one steel strain gauge been attached to the middle rebar in the tension part of the slab (lower portion) and its not accumulation data. The peak displacement is the maximum mid-point displacement measured by contact-less laser sensor and it's not accumulation data.

Table. 4.3: Peak measurements and time of the test result

\begin{tabular}{|c|c|c|c|c|c|c|c|c|c|}
\hline \multirow{2}{*}{$\begin{array}{l}\text { Drop } \\
\text { No. }\end{array}$} & \multirow{2}{*}{ Slab } & \multicolumn{2}{|c|}{ Impact force } & \multicolumn{2}{|c|}{ Total reaction force } & \multicolumn{2}{|c|}{ Steel strain } & \multicolumn{2}{|c|}{$\begin{array}{c}\text { Mid-point } \\
\text { displacement }\end{array}$} \\
\hline & & $\begin{array}{l}\text { Peak } \\
(\mathrm{kN})\end{array}$ & $\begin{array}{l}\text { Time } \\
(\mathrm{ms})\end{array}$ & $\begin{array}{l}\text { Peak } \\
(\mathrm{kN})\end{array}$ & $\begin{array}{l}\text { Time } \\
\text { (ms) }\end{array}$ & $\begin{array}{l}\text { Peak } \\
(\mu \varepsilon)\end{array}$ & $\begin{array}{l}\text { Time } \\
(\mathrm{ms})\end{array}$ & $\begin{array}{l}\text { Peak } \\
(\mathrm{mm})\end{array}$ & $\begin{array}{l}\text { Time } \\
(\mathrm{ms})\end{array}$ \\
\hline$\overline{11}$ & & 1085.48 & 3.39 & 802.68 & 18.24 & 2012 & 7.6 & 78.13 & 30.61 \\
\hline 2 & & 1089.05 & 5.66 & 752.14 & 20.14 & 802 & 9.8 & 86.01 & 34.89 \\
\hline
\end{tabular}




\subsubsection{Impact force and total reaction force}

The impact and total reaction forces-time histories for two drops are found to response typically as shown in following Fig. 4.7.
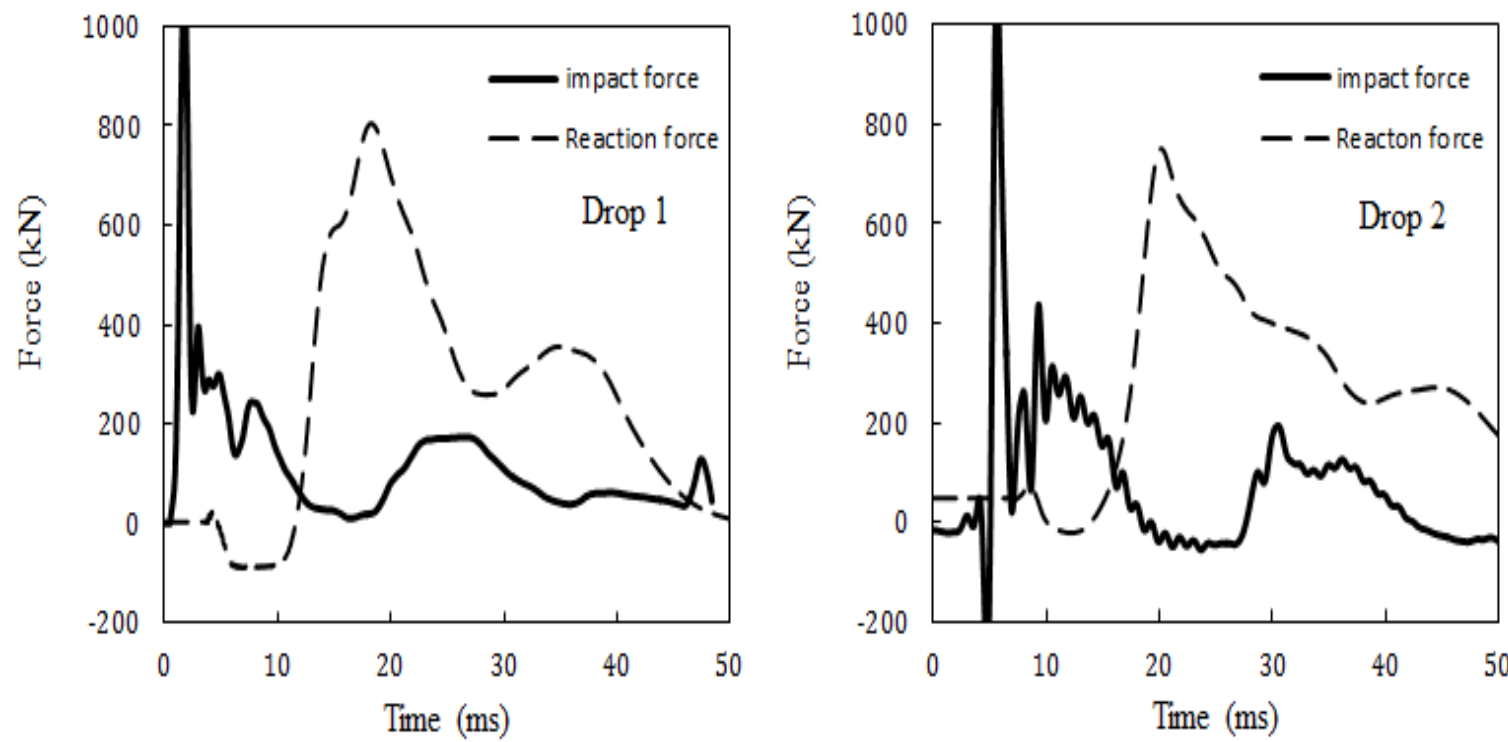

Fig. 4.7: Impact and reaction time histories

Peak impact and reaction forces and corresponding time of each response are listed in Table 4.3. The characteristic values of impact force are summarizes in following Table 4.4.

Table. 4.4: Force characteristics values

\begin{tabular}{c|c|c|c|c|c|c|c}
\hline \hline $\begin{array}{c}\text { Drop } \\
\text { No. }\end{array}$ & Slab & $\begin{array}{c}\text { Impact } \\
\text { velocity } \\
(\mathrm{m} / \mathrm{s})\end{array}$ & $\begin{array}{c}\text { Contact } \\
\text { duration } \\
(\mathrm{ms})\end{array}$ & $\begin{array}{c}\text { Impulse, } \\
\mathrm{I}_{\mathrm{p}}(\mathrm{Ns})\end{array}$ & $\begin{array}{c}\text { Absorbed } \\
\text { energy, } \\
\mathrm{E}_{\mathrm{ab}}(\mathrm{kJ})\end{array}$ & $\begin{array}{c}\text { Input } \\
\text { energy, } \\
\mathrm{E}_{\mathrm{k}}(\mathrm{kJ})\end{array}$ & $\mathrm{E}_{\mathrm{ab} / \mathrm{E}_{\mathrm{k}}}$ \\
\hline \hline 1 & NSC-D & 9 & 50 & 5762.62 & 14 & 19.24 & 0.73 \\
\hline 2 & & 9 & 42.44 & 4051.07 & 12 & 19.24 & 0.62 \\
\hline \hline
\end{tabular}


The impact velocity $V_{i}$ calculated by following equation:

$$
\mathrm{V}_{\mathrm{i}}=\sqrt{ } 2 \mathrm{gh}
$$

Where:-

$\mathrm{g}$ is the standard gravitational acceleration of $9.806\left(\mathrm{~m} / \mathrm{s}^{2}\right)$.

$\mathrm{h}$ is the drop height $(\mathrm{mm})$.

The contact time $T_{d}$ is calculated using the accelerometer reading. The reported impulse $I_{p}$ is the time integration of impact force Fig. 4.8 - Fig 4.9.

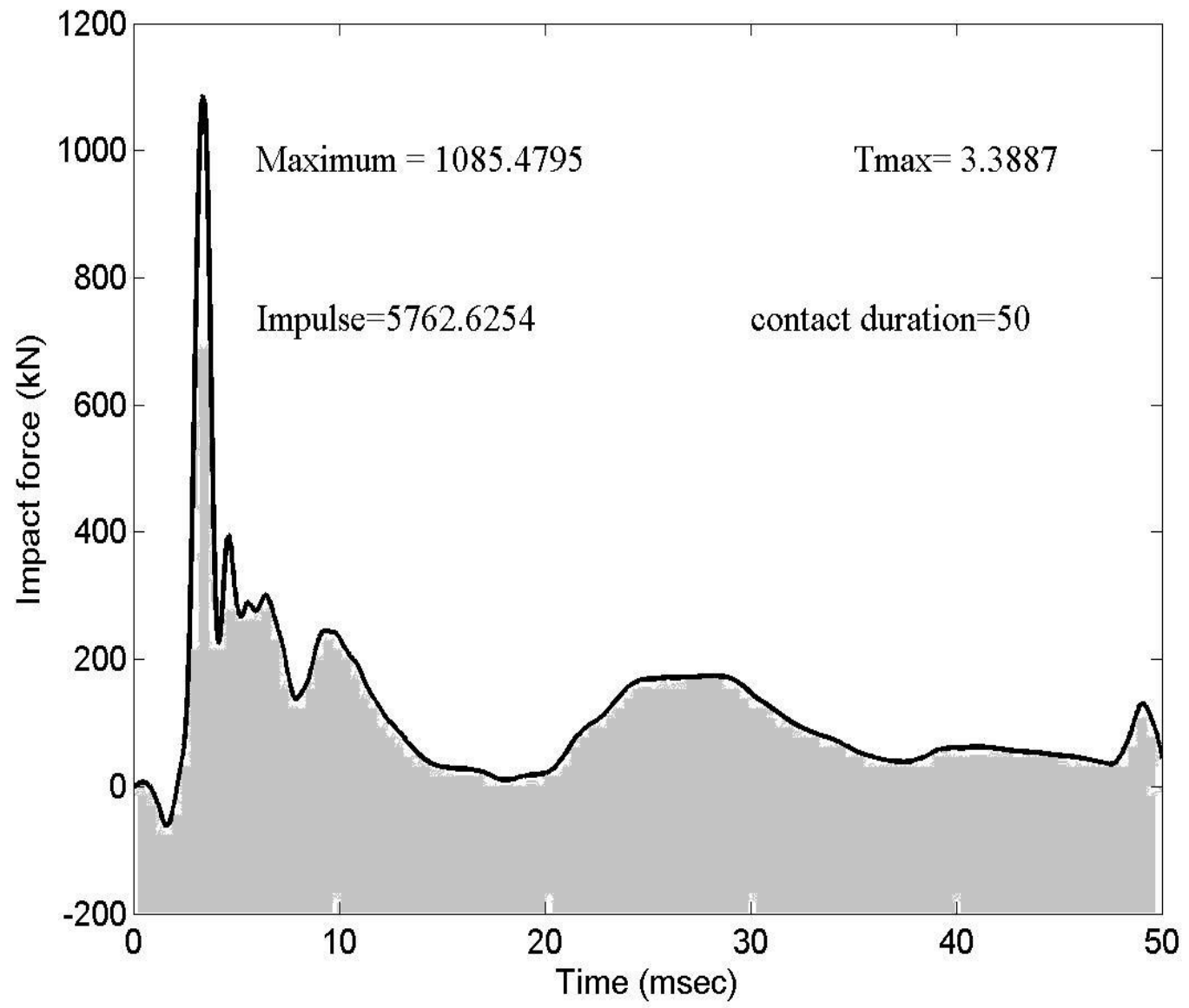

Fig. 4.8: Impact force Time histories for drop 1 


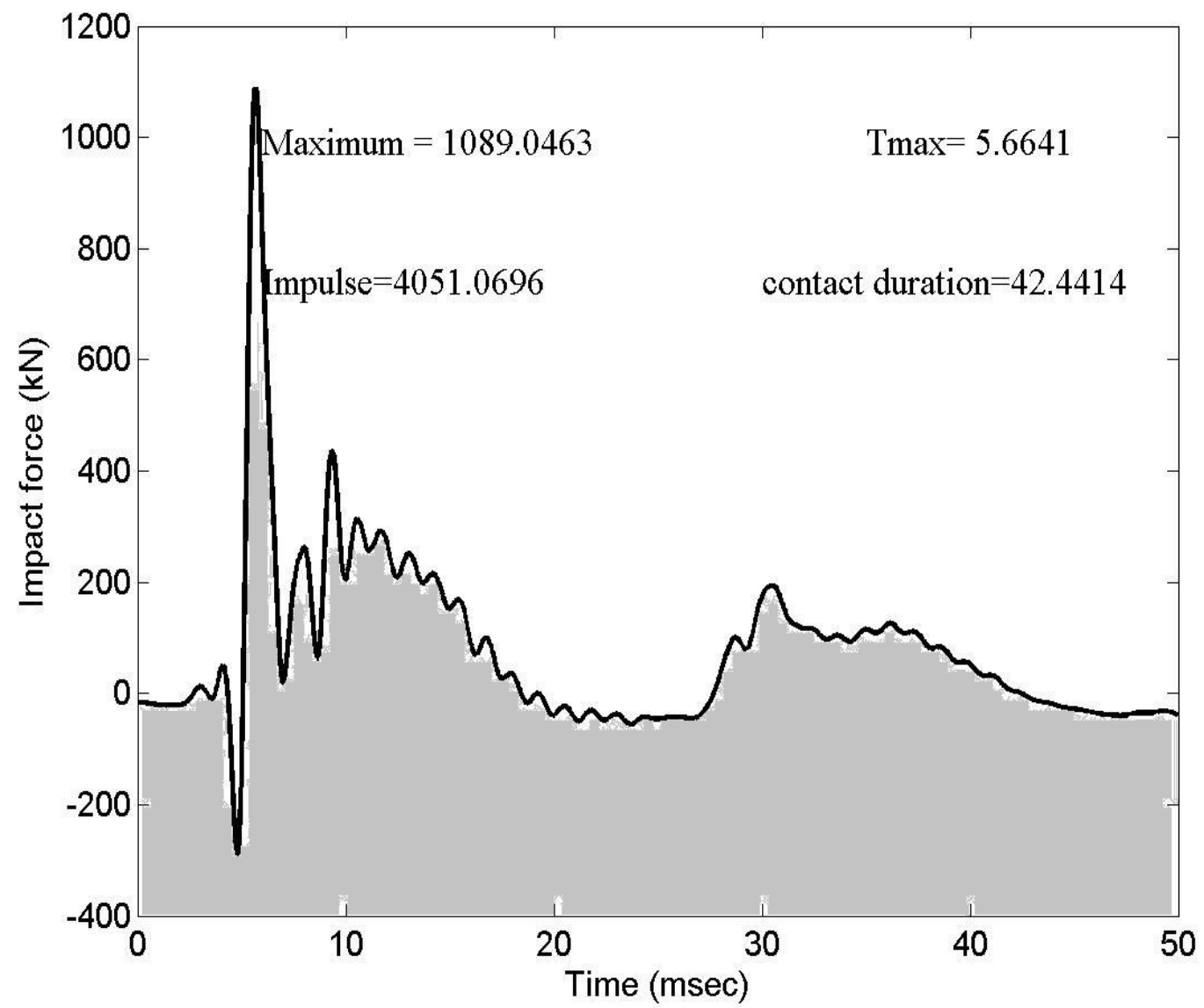

Fig. 4.9: Impact force Time histories for drop 2

Absorbed energy $\mathrm{E}_{\mathrm{ab}}$ is the integration of impact force-displacement curve Fig. 4.10 and the input kinetic energy $E_{k}$ is maximum kinetic energy at instant of impact calculated by the following equation:-

$$
\mathrm{E}_{\mathrm{k}}=1 / 2 \mathrm{m \times \textrm {V } ^ { 2 }}
$$

Where:-

$m$ is the mass of drop-weight of $475 \mathrm{~kg}$. 

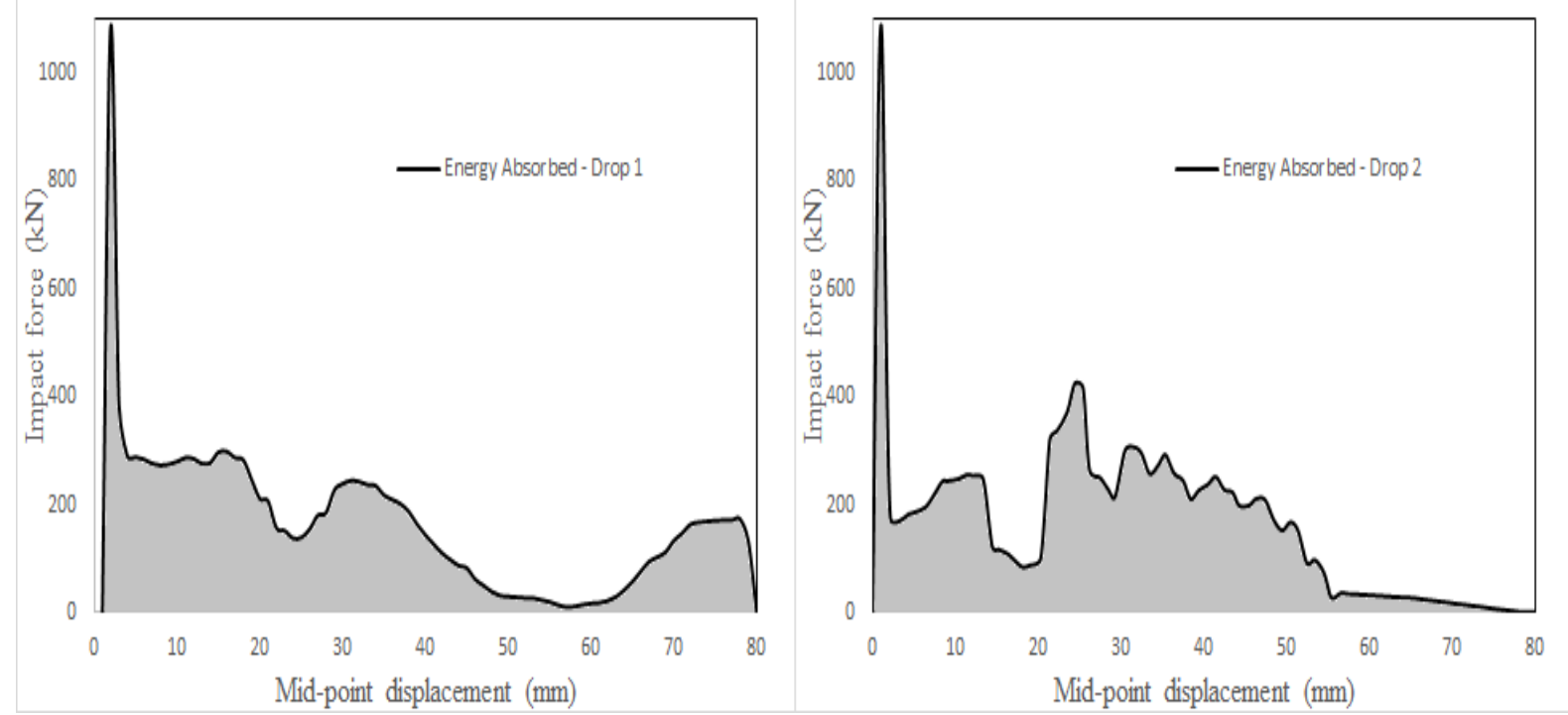

Fig. 4.10: Absorbed Energy $\left(E_{a b}\right)$

\subsubsection{Displacement}

The displacement-time histories was found to respond typically as shown in Fig. 4.11 for midpoint and quarter point. Under each impact test, the plate starts to vibrate in same direction of dropweight motion. After the plate reach the maximum displacement, the plate vibrates in a high frequency at the equilibrium position. When there is no plastic deformation or damage occurred in the plate during impact, the plate is in a free vibration at zero equilibrium position and there is no offset. However, if the plastic deformation is occurred, the plate will vibrate at new equilibrium position. Fig. 4.12 shows displacement-time histories for first and second impact tests at midpoint. 

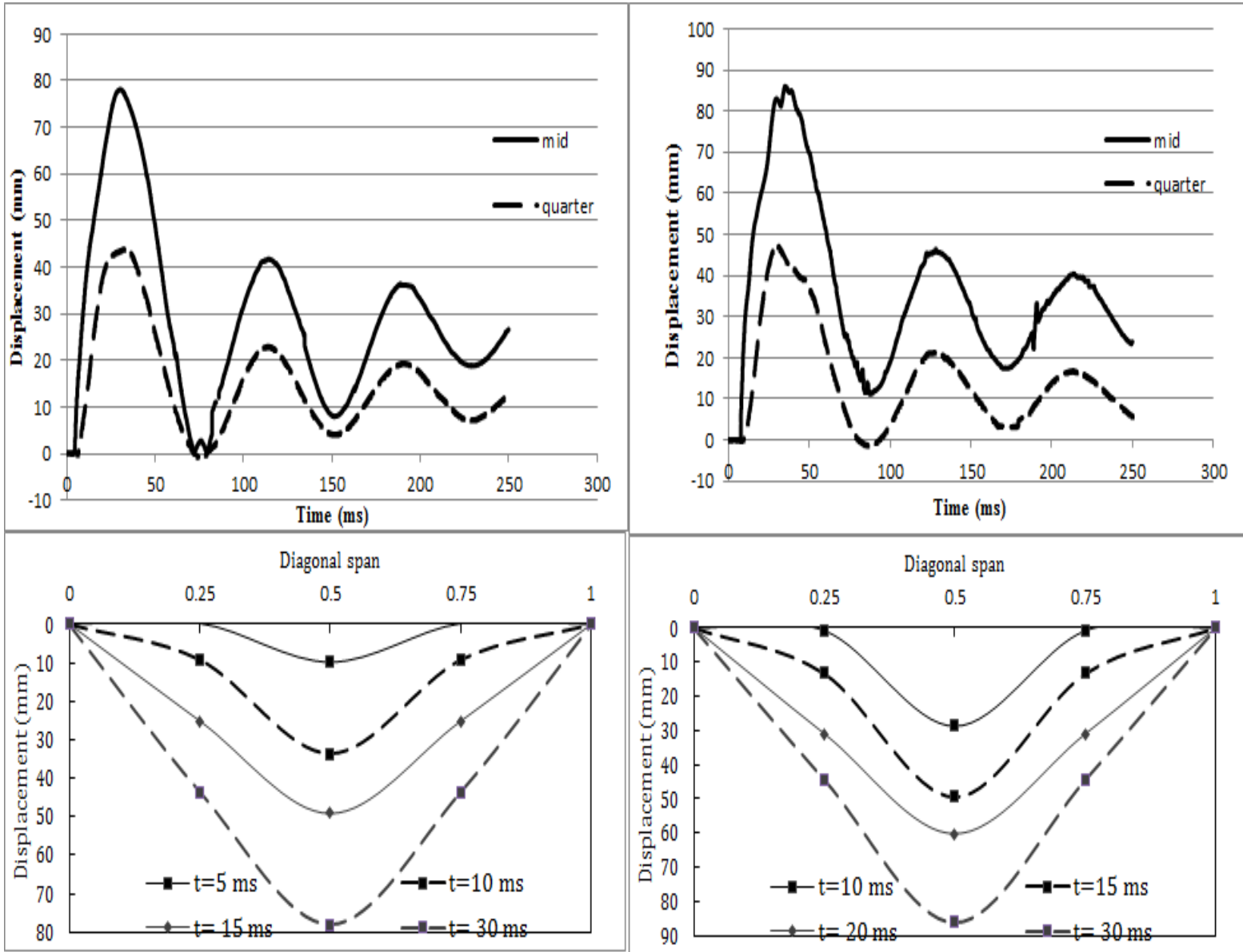

Drop 1

Drop 2

Fig. 4.11: Displacement-Time histories

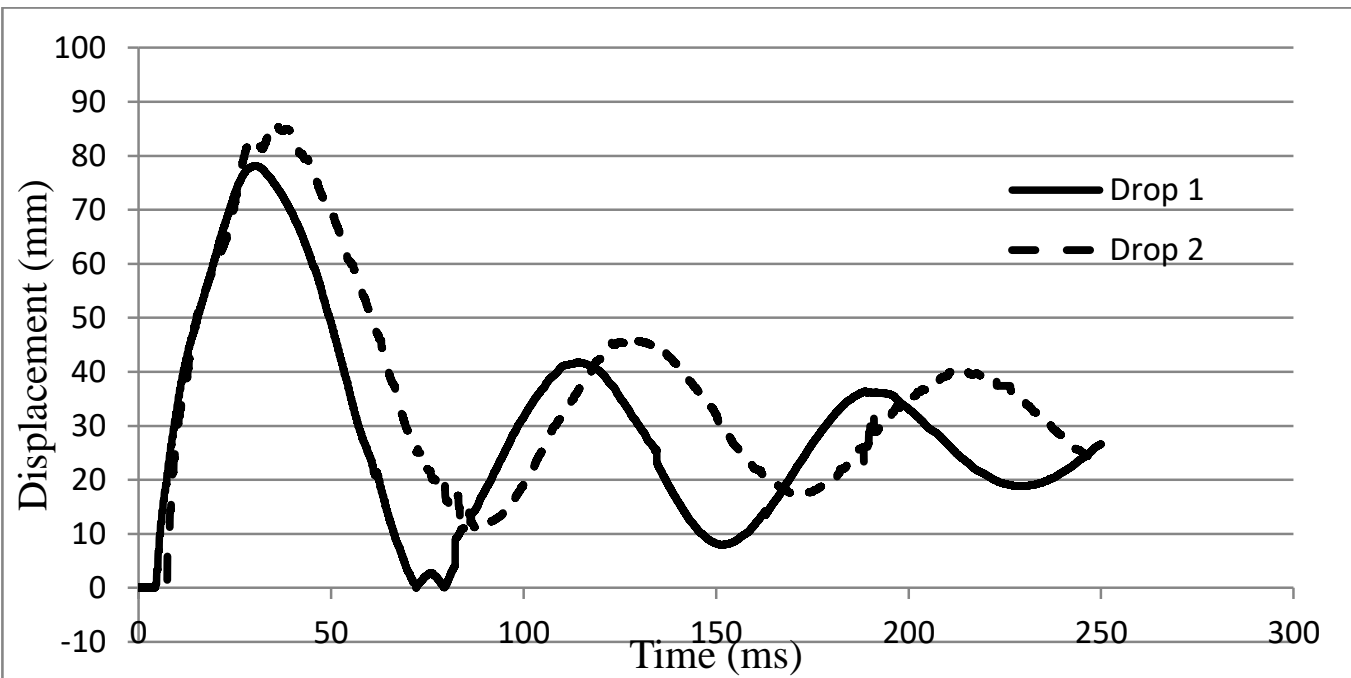

Fig. 4.12: Displacement - time histories for first vs second impact test 


\subsubsection{Damage}

Based on the observed damage and crack development in tested specimens, the specimen is typically failed by localized sudden punching shear failure. Shear cracks are observed before any significant bending cracks developed. Under first impact drop, visible penetration of the dropweight and wide circumferential cracks around impact zone at the bottom surface are observed. In addition, partial scabbing is observed in circumferential crack zone. Under second impact, residual circumferential cracks from previous impact are widened, which significantly led to excessive penetration and concrete scabbing associated with punching shear in the outside perimeter under impact loading zone Fig. 4.14. Steel strain gauges measured large peak strain values followed by residual strain after first impact. Table 4.5 summarizes final damage measurements of the test. The residual displacement, scabbing mass, and penetration depth values are inversely proportional with plate stiffens.

Table. 4.5: Damaged measurements

\begin{tabular}{c|c|c|c|c|c}
\hline \hline \multirow{2}{*}{ Drop No. } & Slab & $\begin{array}{c}\text { Penetration } \\
\text { depth } \\
(\mathrm{mm})\end{array}$ & $\begin{array}{c}\text { Scabbing } \\
\text { mass (kg) }\end{array}$ & $\begin{array}{c}\text { Residual } \\
\text { displacement } \\
(\mathrm{mm})\end{array}$ & $\begin{array}{c}\text { Residual steel } \\
\text { strain }(\mu \varepsilon)\end{array}$ \\
\hline \hline 1 & NSC-D & 5.35 & 18 & 29 & 78.8 \\
\hline 2 & & 22.4 & 26.5 & 31.5 & 544.7 \\
\hline \hline
\end{tabular}

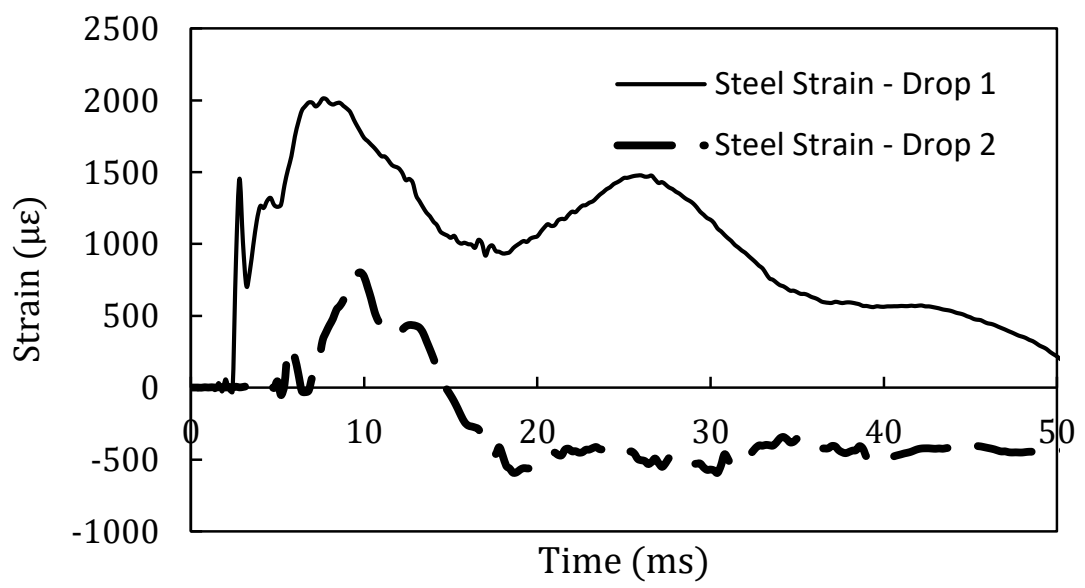

Fig. 4.13: Steel strain - time histories 


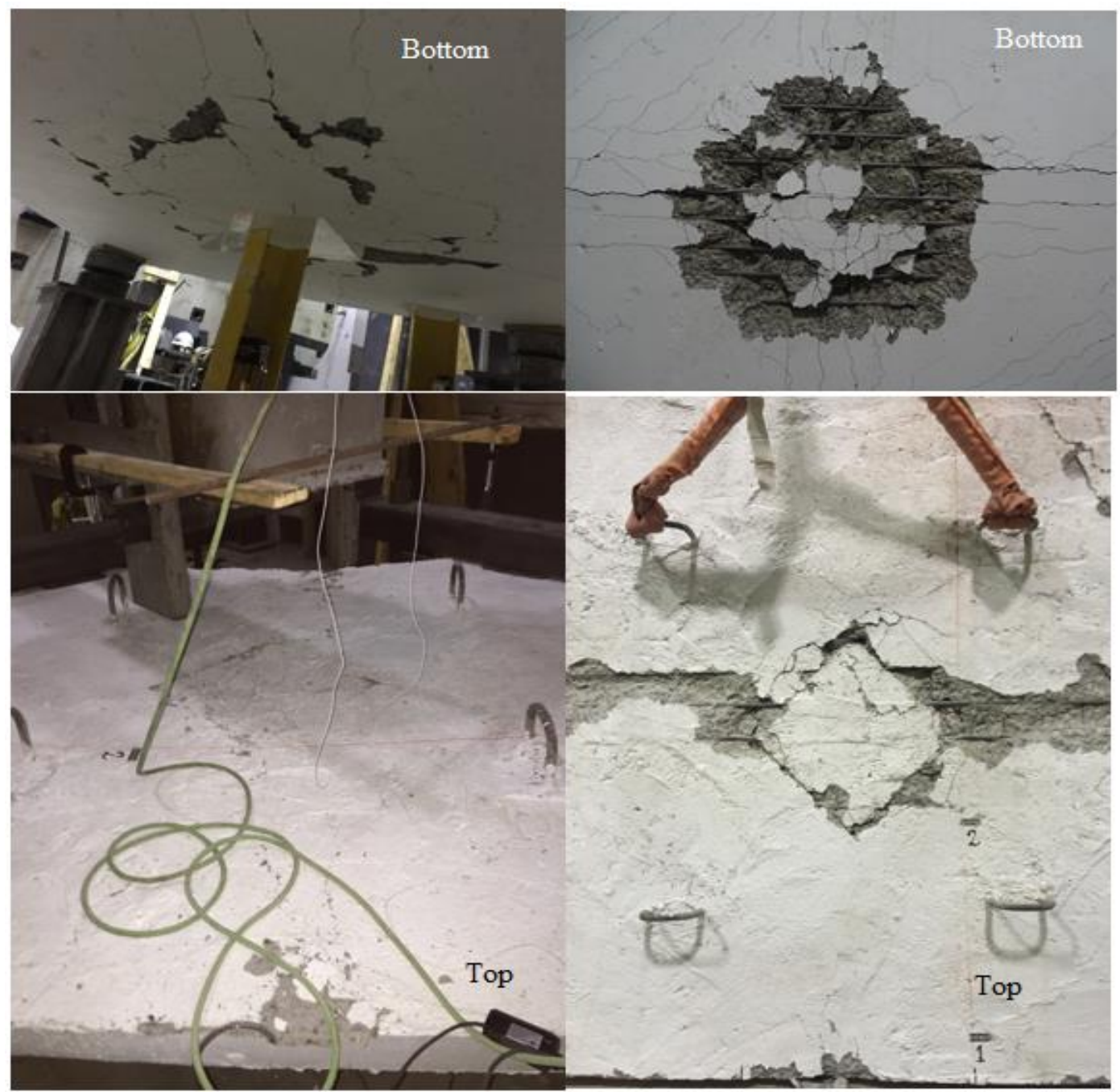

Drop 1

Drop 2

Fig. 4.14: Cracks pattern

\subsection{Discussion of the dynamic results}

Comparing the impact force to the reaction force Fig 4.7, it is obvious that peak amplitude of impact force is greater than that of the reaction force. The reason is most of impact force is used to balance the inertia force or accelerate the plate, while a small portion of impact force is used to deform and fracture the specimens (Saatci and Vecchio, 2009). Additionally, there is a time lag between the maximum impact force and the maximum reaction force. This time lag is due to the stress wave propagation travel from the impact zone to the supports (Saatci and Vecchio, 2009). 
The maximum impact force amplitude and the corresponding contact time duration are affected by the stiffness of the specimen (Fig 4.8 and Fig 4.9). The maximum amplitude of impact force is smaller and the corresponding contact time duration is larger when the specimen at higher stiffness (Drop 1), while the maximum amplitude of impact force is larger and the corresponding contact time duration is lesser when the specimen at lower stiffness ( Drop 2). The energy ratio of absorbed to input kinetic energy clarify the percentage of energy loss due to friction between the drop weight and the guides. It can be seen that the energy ratio values are directly proportion to the stiffness (Fig 4.10).

The plates' displacement exhibited progressively increasing peak followed by residual event displacements (Fig 4.11). For first impact there is no permanent displacement offset which indicates only deformation took place. However, the displacement histories of second impact tests show larger peak and permanent offset (Fig 4.12). This clearly demonstrates that there is a plastic deformation that took place. It is also evident from Fig. 4.12 the natural period of second drop has slightly increased compare to first impact. This period elongation resulted from stiffness loss of damaged plate.

For first impact, the steel reinforcement bars yielded since the strain levels reached values greater than static yield strains reported in Table 4.1. For second impact, steel strain does not reach yield strain (Fig. 4.13). This means the plate failed by the sudden failure of concrete before any significant flexural deformation. 


\section{CHAPTER 5}

SUMMARY AND CONCLUSION 


\section{SUMMARY AND CONCLUSION}

\subsection{Introduction}

This investigation is intended to determine the normal concrete behavior under static and low velocity 'dynamic load' impact test. The experimental program is designed to investigate the failure modes under static and dynamic loading.

\subsection{Research findings}

For the static tests a hydraulic jack lifting up a load cell providing static impact load at the middle of the slab, while for a dynamic test drop weight low velocity impact setup was designed and constructed at structural laboratory of Ryerson University. Following are the major findings of this investigation:

- CSA A23.3 (2014) and ACI 318 (2011) codes can be used to predict the slab failure mode under static load for NSC.

- The impact load contact duration $\mathrm{T}_{\mathrm{d}}$, absorbed energy, load Impulse, and the reaction force losses were directly proportional to the plate stiffness. While, The Penetration, scabbing mass, residual displacement, residual steel strain and periodic time were inversely proportional with the plate stiffness.

- The slab absorption energy of the impact loading were about 1.4 times the static loading. Moreover, the maximum slab deformation was found to be slightly higher for the slab under dynamic loading than static load.

- The specimen failed in localized punching mode under dynamic load, while under static load the specimen failed in ductile punching mode. Furthermore, the same specimen configuration with high strength concrete been tested under same dynamic load and the test revealed that slab failed in ductile punching mode. Based on the previous observation, the failure mode affected by concrete type and load application. And that lead to, the normal strength concrete can't withstand the impact load capacity of $19.30 \mathrm{~kJ}$ and provide a flexural mode failure for the slab designed to fail in flexural. 


\subsection{Recommendation for future studies}

This study is expected to introduce new opportunities for graduate students at Ryerson University to investigate further to find the maximum capacity of the impact load required for normal strength concrete slab to provide a ductile punching failure mode. Following recommendation can be made for future studies:

- For more accurate results, two or more specimens should have been tested for each experiment.

- Using a high capacity dynamic load cell to measure the impact force is recommended since the use of accelerometer to determine the impact force presented several challenges as it requires extensive post-processing validation and filtering.

- For impact load test, using different drop height will provide different load characteristic that can be used to investigate the maximum impact load capacity can be carry out by normal strength concrete. 
$=$ 


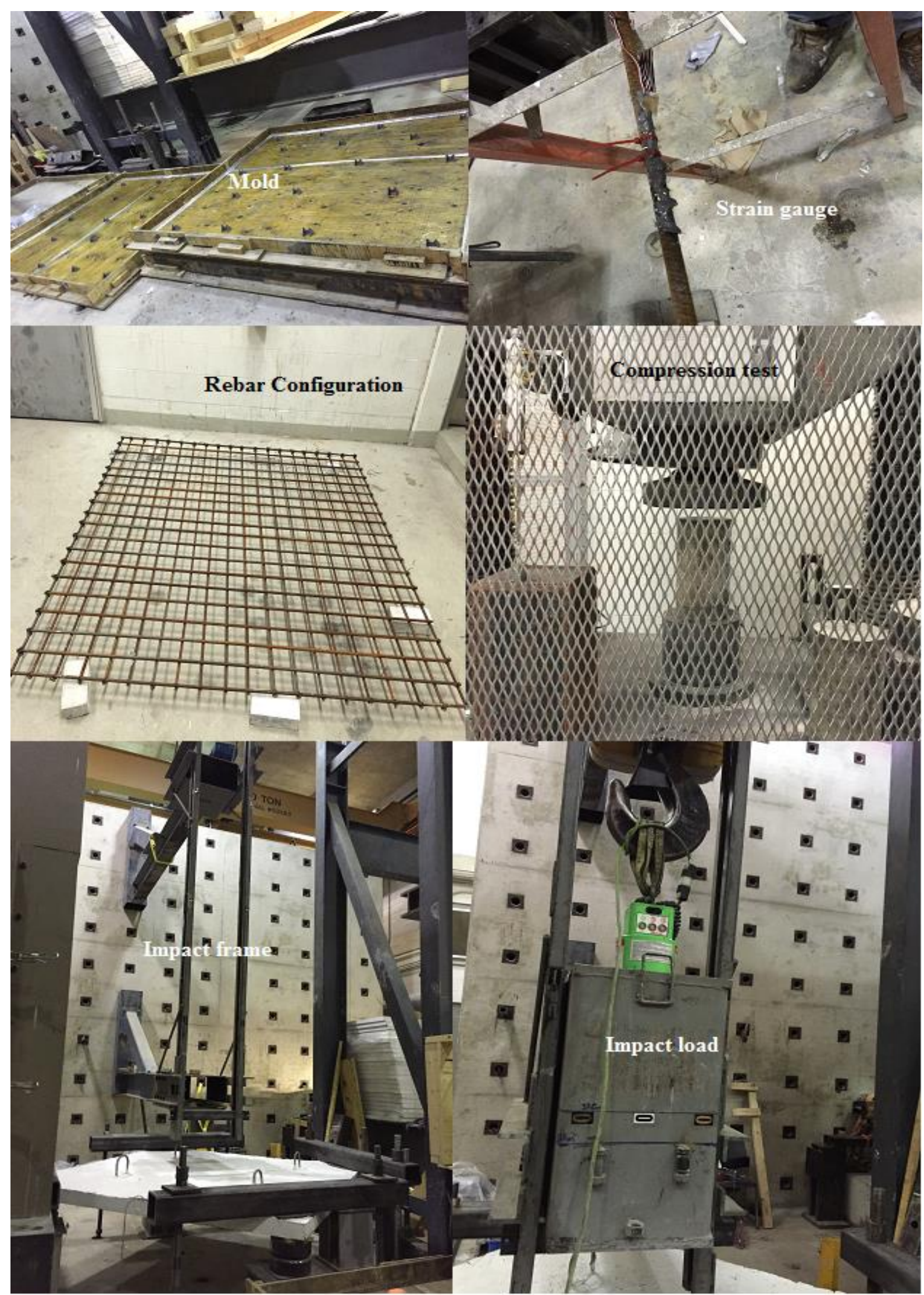




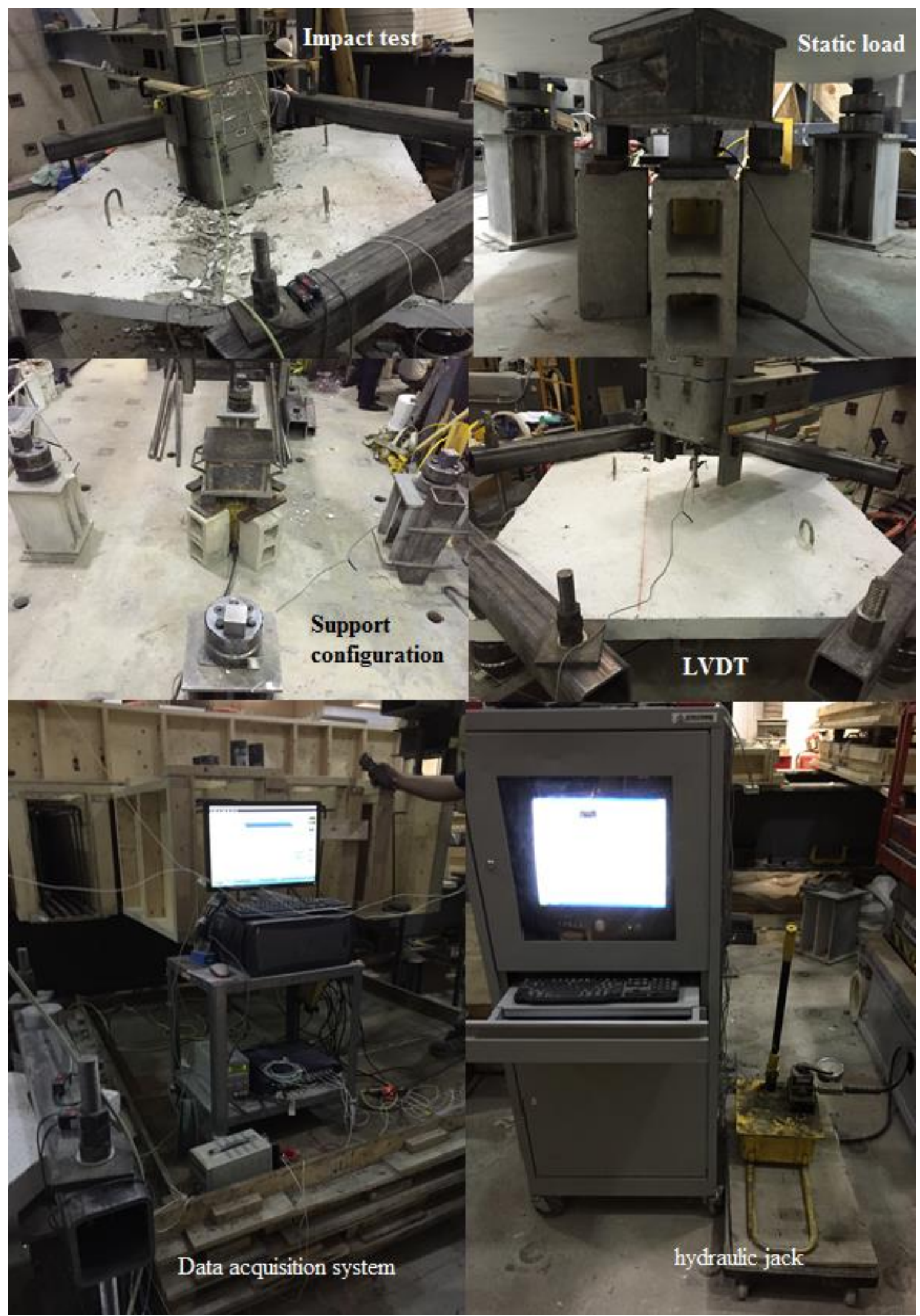




\section{REFERENCES}

ACI Committee 211, (1991). "Standard Practice for Selecting Proportions for Normal, Heavyweight, and Mass Concrete", American Concrete Institute, Report 211.1R-91, 38 pp.

ACI Committee 544, (1988). "Measurement of Properties of Fiber Reinforced Concrete", American Concrete Institute, Report 544.4R-88, Reapproved 2009.

ACI 318M, (2011). "Building code requirements for Structural Concrete", American Concrete Institute, Farmington Hills - USA, 473 pp.

ASTM Standard C39, (2001). "Standard Test Method for Compressive Strength of Cylindrical Concrete Specimens", ASTM International, West Conshohocken, PA, USA, www.astm.org.

ASTM Standard C150, (2016). "Standard Specification for Portland Cement", ASTM International, West Conshohocken, PA, USA, www.astm.org.

ASTM Standard C496, (2004). "Standard Test Method for Splitting Tensile Strength of Cylindrical Concrete Specimens", ASTM International, West Conshohocken, PA, USA, www.astm.org.

Barr, P., Carter, P., Howe, W. and Neilson, A., (1982). "Replica Scaling Studies of Hard Missile Impacts on Reinforced Concrete", In Symposium on concrete structures under impact and impulsive loading, Berlin- Germany, pp. 329-344.

Bazant, Z., and Cedolin, L., (1980). "Fracture mechanics of reinforced concrete", Journal of the Engineering Mechanics Division, 106(6), pp.1287-1306.

Bischoff, P., and Perry, S., (1991). "Compressive behaviour of concrete at high strain rates", Materials and Structures, 24(6), pp.425-450.

CEB-FIP, (1988). "Concrete Structures under Impact and Impulsive Loading - Synthesis Report", Comite EURO-International du Beton, Bulletin D'Information, Lausanne, Switzerland, pp. 184.

Chen, Y. and May, I., (2009). "Reinforced concrete members under drop-weight impacts", Proceedings of the ICE - Structures and Buildings, 162(1), pp. 45-56. 
CSA A23.3, (2014). "Design of concrete Structures", Canadian Standards Association, Mississauga - Canada, 214 pp.

Kennedy, R., (1976). “A Review of Procedures for the Analysis and Design of Concrete Structures to Resist Missile Impact Effects”, Nuclear Engineering and Design, 37, pp.183-203.

Kennedy, G. and Goodchild, C., (2004). "Practical Yield Line Design “, $1^{\text {st }}$ Edition, British Cement Association, Crowthorne, England, 175 pp.

Kishi, N., Mikami, H., Matsuoka, K. and Ando, T., (2002). "Impact Behavior of Shear-failuretype RC Beams without Shear Rebar", International Journal of Impact Engineering, 27(9), pp.955-968.

Kishi, N., Matsuoka, K., Mikam, H. and Goto, Y., (1997). “Impact Resistance of Large Scale RC Slabs", In 2nd Asia-pacific Conference on Shock and Impact loads on Structures. Melbourne, Australia, pp. 213-220.

Kosmatka, S., Kerkhoff, B. and Panarese, (2006). "Design and Control of Concrete Mixtures", Portland Cement Association, Skokie, IL, 372 pp.

Lange, D., (1994). "Long-Term Strength Development of Concrete", Portland Cement Association, Skokie, IL, Report 326, 36 pp.

Li, Q., Reid, S., Wen, H. and Telford, A., (2005). "Local impact effects of hard missiles on concrete targets", International Journal of Impact Engineering, 32(1-4), pp. 224-284.

Malvar, L. and Crawford, J., (1998). "Review of Static and Dynamic Properties of Steel Reinforcing Bars", ACI Materials Journal, 95(5), pp.609-616.

Marzouk, H., (1991). "Creep of High-strength Concrete and Normal-strength Concrete", Magazine of Concrete Research, 43(155), pp. 121-126.

Marzouk, H. and Hussein, A., (1991). "Experimental Investigation on the Behavior of High Strength Concrete Slabs". AC1 Structural Journal, 88(6), pp.701-713.

MathWorks, (2011). “MATLAB ${ }^{\circledR}$ program”. 
Murtiadi, S. and Marzouk, H., (2001). "Behaviour of high-strength concrete plates under impact loading”, Magazine of Concrete Research, 53(1), pp.43-50.

Othman, H. and Marzouk, H., (2015). "Development of a drop-weight impact test setup", Experimental Techniques journal.

Othman, H. and Marzouk, H., (2016). "An experimental investigation on the effect of steel reinforcement on impact response of reinforced concrete plates", International Journal of Impact Engineering, 88, pp. 12-21.

Reinhardt, B., Cornelissen, H. and Hordijk, D., (1986). "Tensile Tests and Failure Analysis of Concrete", Journal of Structural Engineering, 112(11), pp.2462-2477.

Saatci, S. and Vecchio, F., (2009). "Effects of shear mechanisms on impact behavior of reinforced concrete beams", ACI Structural Journal, 106(1), pp. 78-86.

Sawan, J. and Abdel-Rohman, M., (1987). "Impact Effect on RC Slabs: Experimental approach", Journal Of Structural Engineering, 112(9), pp.2057-2065.

Soleimani, S., Banthia, N. and Mindess, S., (2007). "Behavior of RC Beams under Impact Loading: Some new findings", In Proceedings of the 6th International Conference on Fracture Mechanics of Concrete and Concrete Structures. Catania, Italy, pp. 867-874.

Tahmasebinia, F. and Remennikov, A., (2008). "Simulation of the Reinforced Concrete Slabs under Impact Loading". Australasian Structural Engineering Conference, 88 pp.

Xianglin, G., Xianyu, J. and Zhou, Y., (2006). "Basic Principles of Concrete Structures", $1^{\text {st }}$ Edition, Shanghai, China, 606 pp.

Zineddin, M. and Krauthammer, T., (2007). "Dynamic Response and Behavior of Reinforced Concrete Slabs under Impact Loading", International Journal of Impact Engineering, 34(9), pp.1517-1534. 